\title{
Translation to Inter-organizational Systems Integration: The Effect of Power and the Mediating Role of the Obligatory Passage Point
}

\author{
Neil Chueh-An Lee \\ Department of Business Administration \\ Ming Chuan University \\ Taipei City, Taiwan (R.O.C.) \\ Lee.chueh.an@gmail.com \\ Eric T. G. Wang \\ Department of Information Management \\ National Central University \\ Taoyuan City, Taiwan (R.O.C.) \\ ewang@mgt.ncu.edu.tw
}

\begin{abstract}
IOS integration has become a competitive necessity in recent industrial environment. Thus, in the supply chain, dominant firms often try to exert their power to influence their dependent firms to implement IOS integration. However, whether power helps or hurts an integrated IOS implementation is still an unresolved issue. Mixed results on this issue from prior studies demand a further examination on such a context. Based on the circuits of power framework and the concept of obligatory passage point (OPP), this study identifies three factors that mediate the effect of power on the implementation of IOS integration, including competitive necessity, interestingness, and firm readiness. We accordingly develop a theoretical model with six hypotheses. Based on a sample of 134 manufacturing firms and PLS analysis, all hypotheses receive empirical support from the data. The findings suggest that the flows of exercised power and potential power into IOS integration can go through those mediators. Exercised power can promote competitive necessity that lead dependent firms to perceive greater interestingness and achieve higher firm readiness, resulting in a high level of IOS integration. Potential power supplements exercised power in facilitating interestingness and firm readiness. These two types of power also demonstrate different effects on those mediators. While exercised power has a greater impact on competitive necessity and no impact on interestingness, potential power produces an opposite result. This study therefore clarifies the effect of different types of power on IOS implementation. Theoretical and practical implications of the results are provided.
\end{abstract}

Keywords: IOS integration, circuits of power, translation, obligatory passage point, and actor network theory 


\section{Introduction}

Over the past decades, inter-organizational systems (IOS) implementation has attracted significant attention from both academics and practitioners because they believe using IOS can create great value for firms (Rai et al., 2006; Rai and Tang, 2010; Saraf et al., 2007; Subramani, 2004). However, simply using IOS to exchange data is insufficient. Firms, recently, endeavor to establish deeper interconnections with the systems of their trading partners to achieve seamless sharing of information and interconnection of applications in order to gain further benefits from IOS (Barua et al., 2004; Grover and Saeed, 2007; Ramamurthy et al., 1999). This form of tightly coupled trading partnership has been referred to as IOS integration (Grover and Saeed, 2007; Rai et al., 2006; Saraf et al., 2007). By achieving a high level of IOS integration, firms can gain such benefits as increased communications and collaboration, more timely information sharing, improved buyer-supplier relationships, and higher performance (Premkumar and Ramamurthy, 1995; Rai et al., 2006; Rai and Tang, 2010; Ramamurthy et al., 1999; Saraf et al., 2007).

Despite the benefit generating potential of IOS integration, the generated benefits can be distributed unevenly in favor of firms with greater power in the supply chain (Narayanan et al., 2009; Riggins and Mukhopadhyay, 1994; Subramani, 2004). Powerful firms ${ }^{1}$ are likely to gain greater benefits of IOS integration at the expense of their dependent firms (Subramani, 2004). Consequently, dependent firms very often are forced to implement IOS integration, making power play a critical role in such an endeavor. If management misunderstands

\footnotetext{
${ }^{1}$ We term the firm with more power or less dependence as the dominant firm (or powerful firm) and the firm with less power or more dependence as the focal firm (powerless firm, or dependent firm). We use those terms interchangeably.
}

how power operates between the parties, IOS integration may fail due to ineffective use of power. Thus, research on how to facilitate IOS integration through power is important in enhancing our understanding of how to promote IOS integration.

Although extant studies have shed light on IOS implementation through the lens of social-political theories (Chwelos et al., 2001; Hart and Saunders, 1997; Hart and Saunders, 1998; Iskandar et al., 2001; Ke et al., 2009; Narayanan et al., 2009; Robey et al., 2008; Teo et al., 2003), a gap remains in our understanding of how power affects IOS integration (Narayanan et al., 2009). To date, most studies examining power issues have focused on adoption stage rather than integration stage, or called depth usage stage, of IOS implementation cycle (Narayanan et al., 2009). While many studies corroborated the direct relationship between power and IOS adoption (Premkumar and Ramamurthy, 1995), little research has been done on elucidating how power drives IOS integration (Narayanan et al., 2009). While some studies attempt to argue that powerful firms can use their power to promote IOS integration with powerless firms (Hart and Saunders, 1997; Premkumar and Ramamurthy, 1995), others show opposite results (Ramamurthy et al., 1999). Such findings may come from omitting potential mediators (Zhao et al., 2010). Thus, the purpose of this study is to scrutinize how different types of power, i.e., exercised power and potential power, may affect the implementation of IOS integration through the circuit of power framework proposed by Clegg (1989).

We draw on the circuit of power framework and attempt to clarify how power operates in promoting IOS integration. According to the framework, to exert power successfully in a dyadic relationship, the dominant firm has to establish an obligatory passage point (OPP) for the dependent firm (Clegg, 1989). The OPP is the result of "translations" after which the dependent firm would have no choice but to accept the OPP (Callon, 1986). There are four moments within a translation: 
problematization, interessement, enrolment, and mobilization. These moments, as mediating mechanisms being omitted in past studies, can translate the dependent firm from adopting IOS minimally into deeper IOS integration. The dominant firm can exercise its power to influence or to potentially control the translation, thus driving the dependent firm to integrate more tightly with the dominant firm through IOS. Hence, we contend that incorporating the concepts of translation of OPP in a single model should help us gain a better understanding of the indirect effect of power on IOS integration.

Accordingly, this study seeks to understand: (1) what mechanisms are inherent in the influencing process of the dominant firms' power on dependent firms' IOS integration? (2) How and why do these mechanisms mediate the effect of exercised and potential power on IOS integration? To address our research question, we propose a theoretical model based on the circuit of power framework (Clegg, 1989) and Callon's (1986) four moments of translation of OPP. The model is tested by data collected from the manufacturing companies in Taiwan and focuses on the channel relationships in the supply chain. By addressing the power operations in the study of IOS integration, our results contribute to the emerging theories that examine this phenomenon and provide insights into the practice of implementing IOS integration.

The remainder of the paper is organized as follows. The next section reviews the literature on IOS integration and power, followed by our development of the research framework based on the circuits of power framework, obligatory passage points, and the concepts of translation. Section 4 proposes the research model and the associated hypotheses, and Section 5 describes the research method. The empirical results are presented in Section 6 and discussed in Section 7. Finally, Section 8 contains the conclusions.

\section{Conceptual Literature}

\section{IOS Integration}

IOS integration reflects tighter linkages between trading partners' information systems (Grover and Saeed, 2007). IOS integration typically consists of a higher level of functional application integration, such as seamless interconnection of applications, and a lower level of technology stack integration, such as compatible network or hardware (Saraf et al., 2007). By incorporating database interconnection, application integration, and data syntactic and semantic integration as the dimensions, this study defines IOS integration as the extent to which a focal firm's information systems are tightly linked with its dominant, major partner's information systems as a unified whole to facilitate bidirectional information accessing and sharing (Grover and Saeed, 2007; Saraf et al., 2007).

\section{The Antecedents of IOS Integration}

In the IOS literature, adoption and integration are often viewed as two distinct stages in the overall implementation cycle (Narayanan et al., 2009; Robey et al., 2008). However, early studies attempted to find common antecedents of both stages (Narayanan et al., 2009; Robey et al., 2008) based on resource dependence theory (RDT) (Hart and Saunders, 1998), transaction cost economics (TCE) (Son et al., 2005), and innovation diffusion theory (IDT) (Premkumar and Ramamurthy, 1995; Ramamurthy et al., 1999). Unfortunately, the results have been mixed (Iskandar et al., 2001; Narayanan et al., 2009; Premkumar and Ramamurthy, 1995). The antecedents significantly affecting IOS adoption are less significant in facilitating IOS integration (Narayanan et al., 2009). It is fairly reasonable because IOS integration involves greater difficulties in incongruent values and beliefs, conflicting practices, and adversarial behaviors (Kumar and van Dissel, 1996). Resolving those difficulties involves considerable costs. Trading partners then have to be motivated, 
persuaded, coerced, or pressured to integrate IOS (Hart and Saunders, 1998), making power a critical driver of IOS integration. Power, however, also makes the consequences of IOS integration highly unpredictable (Kumar and van Dissel, 1996). Benefits from IOS integration usually are distributed unevenly in favor of dominant firms in the supply chain (Riggins and Mukhopadhyay, 1994; Subramani, 2004). Such results may make firms with less power for appropriating the benefits resist to integrate with more powerful firms through IOS. The concepts and effects of power are discussed below.

\section{Power and IOS Integration}

According to social exchange theory (Emerson, 1976), power refers to the capability of a firm to exert influence on another firm to act on a prescribed manner (Hart and Saunders, 1997). This capability may or may not be exercised by powerful firms. Researchers, thus, distinguish between potential power and exercised power to clarify their effects (Provan et al., 1980). Potential power is that a powerful firm has the capability but does not use it to control another less powerful firm. Potential power has been widely conceptualized as dependence in IOS research (Hart and Saunders, 1998). Dependence thus is a synonym of potential power in this study. Exercised power, on the other hand, is that a powerful firm actually acts to control or influence on the behaviors of another powerless firm. This type of power has a greater impact on interfirm relationships. Although these two types of power have been considered critical in influencing IOS implementation, the empirical results remain mixed (see Table 1).

Most prior studies proposed a direct effect of power on IOS adoption and integration, but the effect on IOS adoption is more significant than on usage and integration (Iskandar et al., 2001; Narayanan et al., 2009; Premkumar and Ramamurthy, 1995). These results reflect that while dominant firms try to exercise their power to influence their dependent firms to adopt IOS, the dependent firms tend to implement IOS in minimal way (Chatfield and Yetton, 2000), without achieving the integration stage (Son et al., 2005). Some studies even showed that exercised power could produce a negative rather than positive influence on IOS usage (Hart and Saunders, 1998). Using power to coerce dependent firms may therefore be a short-term approach (Hart and Saunders, 1998), probably resulting in less desired results.

As Grover and Saeed (2007) argued, IOS integration is established to support bilateral governance that requires trading partners' joint accomplishment and mutual concern for the long-term benefit (Heide, 1994). In order to support such governance, a more stringent initiation process is needed. IOS integration, thus, requires the partners have certain attitudes and values (Heide, 1994), make relationship commitment and trust each other to align their processes, map data elements, and invest in shared resources (Grover and Saeed, 2007; Ramamurthy et al., 1999). While prior studies have focus on the direct effect of power on IOS integration, they neglect to deliberate the nuances of power flows and operations and distinguish the possibly different effects of exercised and potential power on dependent firms. These knowledge gaps motivate us to re-explore the effects of power with a more integrated theoretical framework. Below, we discuss how power operates in the dyadic relationship within the circuits of power framework. 


\begin{tabular}{|c|c|c|c|c|c|c|c|c|c|}
\hline \multirow[t]{3}{*}{ Study } & \multirow[t]{3}{*}{ IOS } & \multicolumn{6}{|c|}{ DV } & \multicolumn{2}{|c|}{ IV } \\
\hline & & \multirow{2}{*}{$\begin{array}{l}\text { Adoption/ } \\
\text { Intention }\end{array}$} & \multicolumn{2}{|c|}{ Usage } & \multirow{2}{*}{$\begin{array}{l}\text { External } \\
\text { integration }\end{array}$} & \multirow{2}{*}{$\begin{array}{c}\text { Internal } \\
\text { integration }\end{array}$} & \multirow{2}{*}{$\begin{array}{l}\text { IOS (EDI) } \\
\text { integration }\end{array}$} & \multirow{2}{*}{$\begin{array}{l}\text { Exercised } \\
\text { Power }\end{array}$} & \multirow{2}{*}{$\begin{array}{c}\text { Potential } \\
\text { Power }\end{array}$} \\
\hline & & & Volume & Diversity & & & & & \\
\hline $\begin{array}{l}\text { Premkumar \& } \\
\text { Ramamurthy (1995) }\end{array}$ & EDI & $x$ & & & $x$ & $x$ & & $X(S, D)$ & $X(N, D)$ \\
\hline Hart \& Saunders (1998) & EDI & & $x$ & $x$ & & & & $\begin{array}{c}X(M, D \\
\mathrm{Ne})\end{array}$ & $X(S, I)$ \\
\hline Chwelos, et al.(2001) & EDI & $x$ & & & & & & $\mathrm{X}(\mathrm{S}, \mathrm{I})$ & $\mathrm{X}(\mathrm{N}, \mathrm{I})$ \\
\hline Iskandar, et al.(2001) & EDI & $\mathrm{x}$ & & & & & $\mathrm{x}$ & & $X(M, D)$ \\
\hline Teo, et al.(2003) & FEDI & $\bar{x}$ & & & & & & & $X(S, D)$ \\
\hline Ranganathan et al. (2004) & Web-SCM & & & & $x$ & & & & $X(S, D)$ \\
\hline Lee \& Lim (2005) & EDI & & $x$ & $x$ & & & $x$ & & $X(M, D)$ \\
\hline Son, et al.(2005) & EDI & & $x$ & $x$ & & & & $X(N, D)$ & \\
\hline Kim, et al.(2005-6) & EDI & & & & & & $\mathrm{x}$ & & $X(S, D)$ \\
\hline Grover \& Saeed (2007) & IOS & & & & & & $x$ & & $X(N, D)$ \\
\hline Son \& Benbasat (2007) & EM & $\mathrm{x}$ & & & & & & & $\mathrm{X}(\mathrm{M}, \mathrm{D})$ \\
\hline Son et al. (2008) & EDI & & $x$ & $x$ & & & & $\begin{array}{c}X \\
(S, D, N e)\end{array}$ & \\
\hline Ke, et al.(2009) & eSCM & $\mathrm{X}$ & & & & & & $\mathrm{X}(\mathrm{M}, \mathrm{I})$ & $X(S, D)$ \\
\hline Zhang and Dhaliwal (2009) & EB & & & & $x$ & $x$ & & & $\mathrm{X}(\mathrm{S}, \mathrm{D})$ \\
\hline Chan and Chong (2012) & RosettaNet & $x$ & & & & & & $X(S, D)$ & $X(S, D)$ \\
\hline
\end{tabular}




\section{Theoretical Foundation and Research Framework}

\section{The Framework of Power}

The circuits of power framework proposed by Clegg (1989) reflects the relational nature of power. Clegg pieces together different insights from prior scholars' conceptualizations of power, including Machiavelli's strategic approach to power, the principle of agnosticism promulgated by actor-network theoreticians (Callon, 1986), and Lukes's three dimensions of power (Lukes, 1974). In the framework, power is a force like electricity, which circulates through episodic circuit, social circuit, system circuit, and obligatory passage points (OPPs). Empirically, power may be contained within the episodic circuit only or it may flow through the dispositional and facilitative routines (Clegg, 1989). In this study, we focus on the episodic circuit and the OPPs to develop our theoretical model. These two concepts help us articulate power operations and enhance our understanding of the differential effects of exercised and potential power on promoting IOS integration.

\section{Research Framework}

Power, in the episodic circuit, emphasizes actions and changes (Clegg, 1989). Episodic power is derived from the capacities of firms grounded in resource control derived from resource dependence theory (Clegg, 1989) and is called potential power in this study. Resources, under appropriate standing conditions, can empower a firm vis-à-vis a specific scope of another firm when utilized through means which implement them (Clegg, 1989), emerging exercised power. In the supply chain context, a dyadic relationship as a standing condition reflects different levels of resource control between the dominant firm and the dependent firm. The dominant firm is empowered to influence the dependent firm. This means that a dominant firm can exert its exercised power and potential power on a dependent firm's decision to adopt IOS, which is the outcome in the episodic circuit. Most prior IOS studies have corroborated this circuit empirically. However, successful episodic power not only involves securing outcomes, which is achieved in the episodic circuit, but also needs to secure or reproduce rules of meaning and membership, which facilitates social circuit (Clegg, 1989). Thus, for further integration, the dominant firm needs to reproduce or transform the dependent firm's rules that govern how it interprets the meaning of IOS; those rules may facilitate or restrict certain common working practices to achieve collective goal, certain attitudes, and common values on IOS integration (Grover and Saeed, 2007; Heide, 1994). IOS integration, by generating new techniques of production and new modes of transaction and operation disciplines, opens up new conduits and passages that can undermine extant entrenched rules and structures (Clegg, 1989), such as extant routines and information system configurations (Rodon and Sese, 2010). These extant rules and structures require to be changed during implementing IOS integration. Those changes can be realized through "translation" pushed by exercised power and potential power.

The "translation," or called sociology of enrolment, is proposed by Callon (1986) and actor-network theoreticians. From this line of research, Clegg draws particularly on the concept of OPPs to complement the circuit of episodic power. In an established power relation, or called a standing condition, a dominant firm seeks methods to "translate" its dependent firm into an OPP. The OPP is the result of "translation" after which the dependent firm has no other choice but to become a part of the dominant firm's network (Silva, 2007). "Translation" refers to the methods by which the dominant firm actually does "translate" resources into networks of control, of alliance, of coalition, of interest and of structure (Clegg, 1989). There are four "moments" of translation: problematization, 
interessement, enrolment and mobilization (Callon, 1986). Through the former three moments, a dominant firm translates the values, beliefs, and activities of its dependent firm. The final moment, mobilization, can be considered as the final outcome of translation that the dependent firm has become a part of network. The dominant firm can use its power to control the "translation" and to reshape the dependent firm's rules and structures through the former three moments to serve its own interests and to reach the final moment, i.e., a high level of IOS integration, as the outcome of the OPP. Therefore, the former three moments of translation are mechanisms that mediate the effects of power on IOS integration as our research framework shows in Figure 1.

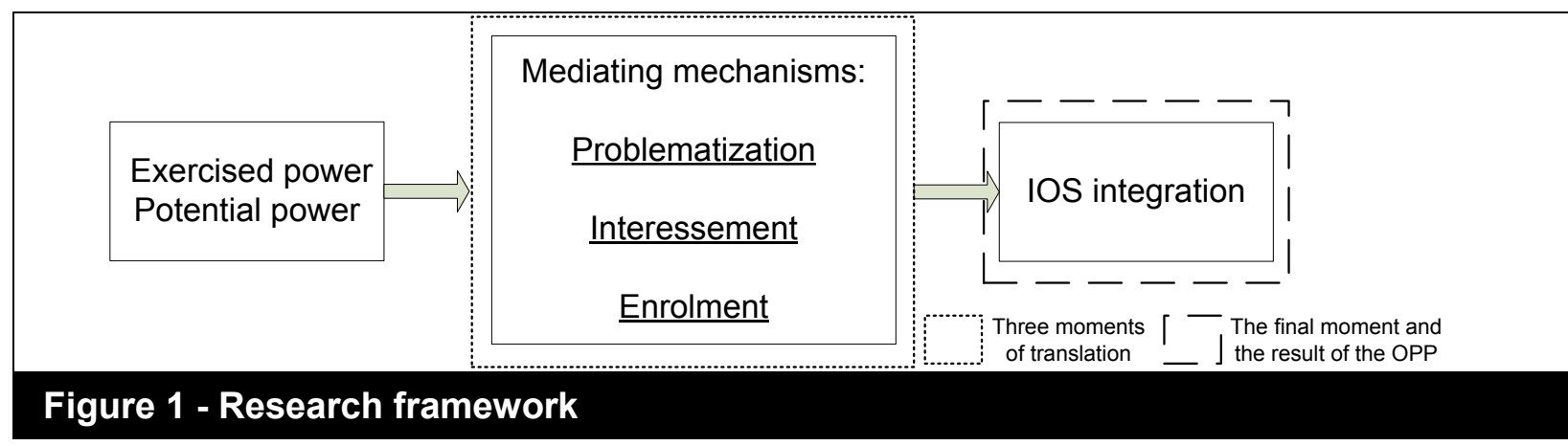

One issue, however, has to be clarified before developing our research model as our theoretical foundation, particularly "translation," reflects a process (Callon, 1986). Each moment of translation implicates various events, which are what key actors do or what happens to them (Van de Ven, 2007). However, our purpose is to apply the theoretical view to identify the mediators neglected between power and IOS integration rather than to elaborate the sequences of events in the process of implementing IOS integration. Thus, we develop a variance model by drawing on the key concepts of events of each moment, integrating these concepts, and mapping the concepts to the context of IOS integration. We first identify the main actors in the context because Callon (1986) argues that "understanding power relationships means describing the way in which actors are defined, associated and simultaneously obliged to remain faithful to their alliances." By understanding how the actors interact in each moment theoretically, we then integrate these concepts, identify mediators, and develop hypotheses. Note that we are not trying to combine a variance model with a process model in a single model (Mohr,
1982). The concepts drawn from each moment are explored to identify an appropriate construct. Nonetheless, we still keep in mind the cautions advised by Mohr (1982) who argues that the outcomes of variance and process models differ in form and ontology and should not be confused (Newman and Robey, 1992). Moreover, because the four moments in reality can overlap (Callon, 1986), we thus pay more attention to the discriminant validity of our constructs in terms of conceptual mapping, theoretical definitions, and statistics examinations. Although the nature of translation brings above difficulties for us, the theoretical interrelationships between the four moments, which means the moments can influence each other (Callon, 1986), however can help us develop theoretical conjectures about the relationships between constructs. Further, Callon (1986) notes that the four moments do not represent stages and might not occur - or be detected - in this order, which alleviates the importance of time ordering, helping us justify our variance model. In what follows, we develop our research model. 


\section{Model Development}

The development of our model proceeds as follows:

- We first identify the main actors involved in power operations and flows in our research context as shown in Table 2.

- Based on OPP and translation, we explain how and why these actors interact and enact power with each other in each moment.
- We then map these interactions among actors into the context of IOS integration to identify appropriate constructs for representing the outcomes of these interactions.

Therefore, our hypothesis deduction is based on the theoretical interactions among actors. Such an approach can strengthen and complement the inferred processes in our research model (Newman and Robey, 1992).

\begin{tabular}{|c|c|}
\hline Actors & Descriptions \\
\hline $\begin{array}{l}\text { Powerful firms } \\
\text { (dominant firms) }\end{array}$ & $\begin{array}{l}\text { The powerful firms can influence the powerless firms to implement IOS integration in order to } \\
\text { gain further benefits. }\end{array}$ \\
\hline $\begin{array}{l}\text { Powerless firms } \\
\text { (focal firms) }\end{array}$ & $\begin{array}{l}\text { The powerless firms may have their own ways of doing business with the powerful firms in } \\
\text { order to protect their self-interests. }\end{array}$ \\
\hline IOS & $\begin{array}{l}\text { IOS is a type of information systems that interconnects different firms' internal systems to } \\
\text { support information sharing. }\end{array}$ \\
\hline Competitors & $\begin{array}{l}\text { The firms compete with the powerless firms. They manufacture same products as those } \\
\text { supplied by the powerless firms. }\end{array}$ \\
\hline Other suppliers & $\begin{array}{l}\text { Suppliers of the same powerful firms but are not competitors of the powerless firms. The } \\
\text { relationships between other suppliers and powerless firms are built up when they deal with } \\
\text { the same powerful firm. }\end{array}$ \\
\hline
\end{tabular}

\section{Problematization}

The first moment is problematization that involves the attempt by a powerful firm to enroll a powerless firm to become its agency by positing the indispensability of their "solutions" for the powerless firm's problems (Callon, 1986). During problematization, a powerful firm frames problems in its own terms, identifies a powerless firm, and highlights how the problems affects it (Sarker and Sidorova, 2006) and blocks its own road to interests (Callon, 1986). The powerless firm recognizes that it cannot attain what it wants by itself. The powerful firm, therefore, persuades the powerless firm in the network that the problems are worth dedicating resources to its solutions (Callon, 1986).
Problematization is achieved when the powerless firm recognizes that aligning with the powerful firm and detours from extant approaches are necessary for gaining benefits (Callon, 1986). Consequently, the outcomes of problematization are that the powerless firm recognizes that the solutions as indispensable and a series of problems behind the solutions are being reflected.

\section{Mapping Problematization to IOS Context}

We conceptualize the outcome of problematization as competitive necessity of IOS that refers to the extent to which a focal firm recognizes that establishing IOS integration with its dominant firm is competitively necessary and thus an indispensable solution for gaining 
competitiveness. In general, the focal firm and its dominant firm have divergent objectives and approaches to gaining their own interests (Rodon et al., 2008; Rodon and Sese, 2010). During problematization, the dominant firm frames critical problems and leads the focal firm to recognize that movements through IOS integration are required to maintain its interests and that the dominant firm stands on the same side with it. The critical problems have often been proposed in the literature, such various pressures as industrial competitive pressure and relationship pressure from competitors and other suppliers (Chwelos et al., 2001; Huang et al., 2008; lacovou et al., 1995; Ke et al., 2009; Teo et al., 2003). These external pressures often cause the focal firm's road to benefits to be blocked by the problems of losing competitiveness and therefore business with the dominant firm. Of course, other problems may have same effects, but we, however, focus mainly on a state that the focal firm recognizes the necessity of IOS integration.

\section{Power and Competitive Necessity of IOS Integration}

Exercised power refers to that the dominant firm exerts its influence, with coercive and persuasive power, on the focal firm to establish IOS integration in support of transactions and operations (Hart \& Saunders, 1997; Hart \& Saunders, 1998). The dominant firm can exercise its power to channel the focal firm into problematization and therefore to reshape the focal firm's interpretations of whether IOS integration is necessary (Callon, 1986; Clegg, 1989). By persuasively informing the focal firm about competitors' implementation of IOS integration, the dominant firm can frame the problem as such that without integrated IOS, the focal firm would lose competitive advantages on interfirm operations compared with competitors; by coercively threatening the possibility of relationship dissolution (Frazier et al., 2009), the dominant firm can highlight how the problem would affect the focal firm. Thus, competitive conditions allow the dominant firm to secure the substantive conditions for persuading the focal firm that the power makes contextual good sense (Clegg, 1989); the dominant firm therefore has the legitimacy to exercise the above influences to shift and bring pressures to the focal firm. Consequently, these pressures reflect the dominant firm's influences on the focal firm's sense and decision making on whether IOS integration is a competitive necessity (Ke et al., 2009; Teo et al., 2003) and worth dedicating resources into its implementation. Under such an influencing process, the focal firm would regard IOS integration as a competitive necessity in doing business with the dominant firm. Prior studies also support that a dominant firm's exercised power increases its dependent firm's perceived pressures (lacovou et al., 1995; Ke et al., 2009; Kumar et al., 1995). We thus propose the following hypothesis:

Hypothesis 1: Exercised power by a dominant firm is positively associated with the competitive necessity of IOS integration perceived by its dependent firm.

\section{Interessement}

The second moment is interessement that refers to the process of "interesting" a powerless firm in the powerful firm's own agency. Interessement is a group of actions by which the powerful firm attempts to impose and stabilize the identity of the powerless firm into interesting in a solution that can benefit both parties (Callon, 1986). To interest the powerless firm, the powerful firm can build devices or approaches placed between the powerless firm and all other invisible entities who want to define the powerless firm's identities; the powerful firm needs to cut or weaken all the links between the powerless firm and the other entities (Callon, 1986). To do so, the properties and identities of the powerless firm are consolidated and/or redefined during interessement. The outcome of interessement is that the powerless firm is interested in the powerful firm's solution due to its future benefits. 


\section{Mapping Interessement to IOS Context}

During interessement, the dominant firm needs to interest the focal firm in IOS integration. The dominant firm can build such incentive mechanisms as increasing purchasing volumes to attract the focal firm (Premkumar and Ramamurthy, 1995). By the mechanisms, the dominant firm cuts or weakens the invisible entities that may cause the focal firm to refuse IOS integration, such as costs and risks (Kauremaa et al., 2010). Consequently, we conceptualize the outcome of interessement as interestingness in IOS integration that refers to the extent to which the focal firm is interested in implementing IOS integration with its dominant partner due to the benefits of IOS integration.

\section{Competitive Necessity and Interestingness in IOS Integration}

According to "translation," problematization is adjacent to interessement (Callon, 1986). Successfully translating the focal firm's attitudes and values of IOS integration from unnecessary into necessary leads the focal firm into a positive identity of IOS integration. The dominant firm can adopt incentive mechanisms as mentioned above to lure the focal firm and, meanwhile, evidence the benefits of IOS integration by showing the successful cases of competitors and other suppliers, convincing the focal firm that the interests shown by the dominant firm are consistent with its own interests (Callon, 1986). Such a process is similar to network effects (Katz and Shapiro, 1985); when more competitors and other suppliers have implemented IOS integration and succeeded in enhancing transaction efficiency and relationship, the focal firm's interestingness in IOS integration is gradually strengthened (Zhu, Kraemer, Gurbaxani, et al., 2006). Prior studies, such as Yao et al. (2007), also demonstrate that sociopolitical influences, such as the pressures and recognition from other firms in the supply chain, affect the perception of the benefits that can be derived from the use of IOS. Thus, we propose the following hypothesis:

Hypothesis 2: A dependent firm's perceived competitive necessity of IOS integration is positively associated with its interestingness in IOS integration.

\section{Potential Power and Interestingness in IOS Integration}

Potential power refers to the ability of a dominant firm to get a focal firm to undertake an activity that the focal firm would not normally do (Emerson, 1962; Grover and Saeed, 2007; Son et al., 2005). Potential power is a function of (1) the proportion of the focal firm's need for resources or services that the dominant firm can provide, and (2) the inverse proportion to the availability of alternative firms capable of providing the same resources or services. With potential power, the dominant firm can impose and stabilize the focal firm's interestingness in IOS integration. Such an influence may not emerge obvious actions but can be realized through imperceptible approaches. By controlling scarce and important resources, the dominant firm can make the focal firm to recognize the importance of maintaining the relationship in order to reduce the uncertainty of gaining resources, securing survival interests, and achieving desired goal (Casciaro and Piskorski, 2005; Pfeffer and Salancik, 2003). These give the focal firm a strong incentive to ensure that the relationship prospers over time (Lusch and Brown, 1996). Integrating IOS with the dominant firm is a kind of relationship-specific investment that provides a good solution proposed during problematization for enhancing their interfirm operations and reducing the uncertainty of resource availability. Those benefits meanwhile seem being placed between the focal firm and other invisible entities, such as the potential costs and risks of IOS integration (Kauremaa et al., 2010), extant practices and technologies (Grover and Saeed, 2007), and autonomy (Mohr and Spekman, 1994), that attempt to define the focal firm's identity of IOS 
integration otherwise (Callon, 1986). Consequently, the focal firm is less likely to deny the possible benefits that can be obtained by tighter coupling with the dominant firm with potential power. The dominant firm is thus able to cut and weaken the links of those invisible entities with the focal firm. We thereby propose the following hypothesis:

Hypothesis 3: Potential power of a dominant firm is positively associated with its dependent firm's interestingness in IOS integration.

In fact, the former two moments focus on changing the focal firm's attitudes and values of IOS integration. These like a process that initiates the building bilateral governance, which involves certain attitudes or values (Heide, 1994). The dominant firm influences the focal firm by translating its goals, orientations, motivations, and interests toward favoring IOS integration. The next two moments are to influence the focal firm actually being enrolled into the network of the dominant firm.

\section{Enrolment}

The third moment is enrolment that refers to the process through which a powerful firm seek to construct agreed meanings and ally with a powerless firm (Clegg, 1989). The aim of enrolment is to build up agreements between the two firms. During enrolment, the powerful firm is trying to convince the powerless firm to play the role defined for it by the powerful firm (Elbanna, 2006). This however does not imply excluding the powerless firm from its pre-established roles in other alliances (Callon, 1986; Elbanna, 2006). Thus, enrolment involves multilateral negotiations (Callon, 1986), wherein the powerful firm is ready to make concessions to lure and consolidate the powerless firm into its trap and thereby its alliance (Callon, 1986; Silva, 2007). Finally, if the powerless firm is to be enrolled, it must be willing to involve in the alliance of the powerful firm. Therefore, the outcome of enrolment is that the powerless firm is willingly to engage in the activities of the alliance.

\section{Mapping Enrolment to IOS Context}

It should be appropriate to consider a dependent firm's readiness for IOS integration to be the outcome of enrolment, as Callon (1986) describes that enrolment is more certain when an actor is willing to engage in a network. In his case study of St Brieuc Bay, the actor is the scallop that anchors itself to the collectors, resulting in achieved enrolment. In the IOS context, the focal firm as the scallop is willing and ready to invest resources in IOS integration as the collectors. Accordingly, to realize the benefits of IOS, the focal firm must ally with the dominant firm and play the defined role in IOS integration (Callon, 1986). It is not to say that the focal firm is necessary and sufficient to become a part of the network of IOS integration. The focal firm may still be a part of pre-established network practicing its extant information systems, processes, and resource allocation mechanisms (Redondo et al., 2009; Rodon and Sese, 2010). Thus, the dominant firm may have to use its power to lure the focal firm to implement IOS integration and to mutually adjust their original systems, processes, and resources allocation (Grover and Saeed, 2007). When the focal firm is willing to build up a high level of readiness for IOS integration with the dominant firm, the dyadic firms should have reached the outcome of enrolment. In this paper, we define firm readiness for IOS integration as the extent to which a focal firm is ready and willing to implement IOS integration (Barua et al., 2004; Chwelos et al., 2001). That is, the focal firm has reconfigured its resources and structures into a ready status for implementing IOS integration.

\section{Effects of Competitive Necessity and Interestingness on Firm Readiness for IOS Integration}

The focal firm is likely to engage in the necessary activities for implementing IOS integration when it recognizes the competitive necessity of IOS integration as 
suggested by the dominant firm. By showing a series of problems during problematization, the dominant firm then can try to convince the focal firm to model itself as its competitors and other suppliers who play their roles and work well in their networks (Callon, 1986). The focal firm thus may comply with the way of imitating the competitors and other suppliers. This seems a collective action that can lead the focal firm to acquire status-conferring legitimacy or fitness in its industry and supply chain structure (DiMaggio and Powell, 1983; Teo et al., 2003). This implies that the focal firm can release its pressures from being a heterogeneous role in the industry and the structure. Further, by highlighting the significant influences of the problems (Callon, 1986), the dominant firm can lure the focal firm to change its extant practices. For example, within the focal firm, top management therefore may succumb and translate its attitudes into which enrolling into IOS integration can succeed as the competitors and other suppliers. Through these approaches, the dominant firm can build up the legitimacy for the focal firm to invest resources into IOS integration and align its processes and technology configurations with the dominant firm, resulting in higher readiness for IOS integration. Accordingly, we propose the following hypothesis:

Hypothesis 4a: A dependent firm's perceived competitive necessity of IOS integration is positively associated with its firm readiness for IOS integration.

Interestingness in IOS integration should motivate the focal firm to go through enrollment and perform the necessary activities for implementing IOS integration. Callon (1986) argues that "interessement achieves enrolment if it is successful; to describe enrolment is to describe the groups of multilateral negotiations, trials of strength and tricks that accompany the interessements and enable them to succeed." Thus, to enroll the focal firm is first to negotiate with it as well as its internal actors such as top management. By maintaining the status quo, internal actors may interrupt the focal firm's enrollment into IOS integration (Kauremaa et al., 2010; Lu et al., 2006; Rodon and Sese, 2010). To negotiate with them, the dominant firm can interest them in IOS integration. High levels of interestingness in IOS integration also motivate a positive attitude of the dependent firm's top management toward IOS integration, creating incentives for investing resources and taking risk on changing extant practices necessary for IOS integration (Clegg, 1989, p. 192; Kauremaa et al., 2010; Lu et al., 2006; Rodon and Sese, 2010). It is true that interestingness in IOS integration about its benefits would never be realized unless the focal firm can actually enroll into the network of IOS integration (Callon, 1986). Accordingly, we propose the following hypothesis:

Hypothesis 4b: A dependent firm's interestingness in IOS integration is positively associated with its firm readiness for IOS integration.

\section{Mobilization}

The final moment is mobilization that refers to the set of methods that powerful firms use to ensure that the representations of interest that powerless firms make are in fact themselves fixed (Callon, 1986; Clegg, 1989). As the word indicates, to mobilize is to render powerless firms mobile which were not so beforehand. This term emphasizes a definite physical reality is materialized and stabilized through all the necessary displacements accomplished (Callon, 1986; Law, 1986). Therefore, the network results in a single actor, which can be treated as a black-box (Latour, 1987).

\section{Mapping Mobilization to IOS Context}

In the IOS context, this study holds that the outcome of mobilization is the extent of IOS integration achieved when all the necessary displacements have been accomplished such as mapping data elements, aligning processes, and investing in shared resources (Grover and Saeed, 2007; Ramamurthy et al., 1999). A high level of 
IOS integration also represents a stable and tighter coupling between two firms with IOS (Grover and Saeed, 2007). Such seamless interconnection of systems and supply chain practices therefore can be seen as a blackbox of dyadic firms.

\section{Firm Readiness and IOS Integration}

Firm readiness have been demonstrated to be critical in facilitating IOS usage (Chwelos et al., 2001; Zhu, Kraemer, and Xu, 2006). However, in this study, we emphasize that the dominant firm mobilizes the focal firm into IOS integration. At first, the dominant firm and the focal firm are actually dispersed without an integrated IOS and not easily accessible to each other's information (Callon, 1986). Through a series of settlement, all actors, including some invisible actors and the focal firm's internal actors, are reassembled at a certain place, reflecting a high level of firm readiness. Different facets of readiness materialize a series of definite displacements, such as from the obstacles of top management (Zhu, Kraemer, and $\mathrm{Xu}, 2006)$, lack of financial support (Chwelos et al., 2001; Zhu, Kraemer, and $\mathrm{Xu}, 2006$ ), to divergent processes and technologies of dyadic firms (Kambil and Short, 1994; Narayanan et al., 2009; Rodon and Sese, 2010) to stabilize the focal firm into IOS integration. Consequently, the focal firm is included in the network of the dominant firm, achieving a higher level of IOS integration with the dominant firm. Accordingly, we propose the following hypothesis:

Hypothesis 5: Firm readiness for 105 is positively associated with IOS integration.

Overall, our research model is as illustrated in Figure 2, and it elaborates the relationships among exercised power, potential power, and some mediators proposed in prior studies (Chwelos et al., 2001; Hart and Saunders, 1997; Hart and Saunders, 1998; Ke et al., 2009; Son et al., 2008; Teo et al., 2003). We believe that these mediators have the potential to explain why the effects of exercised and potential power on IOS integration have been mixed empirically.

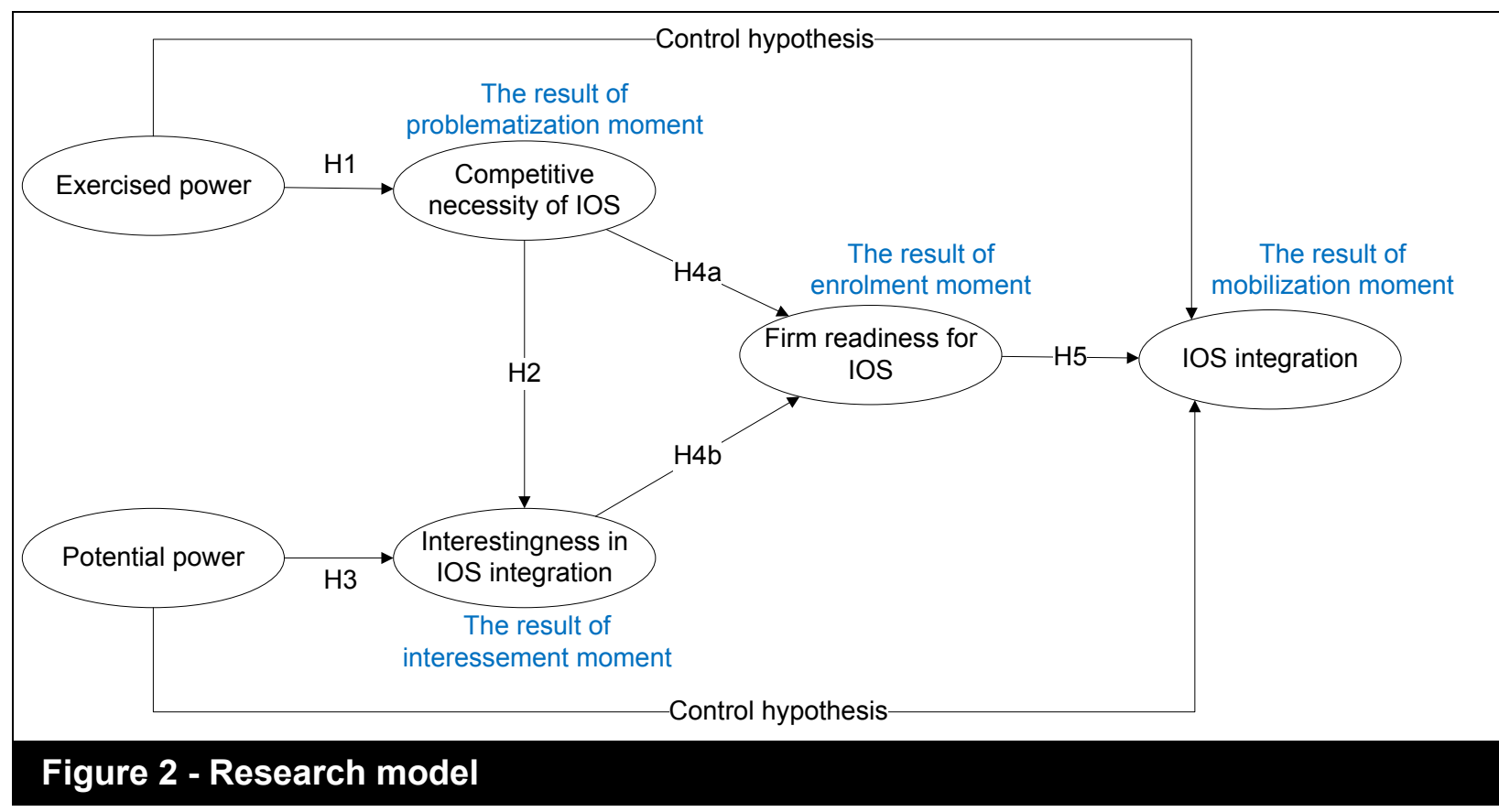




\section{Control Variables}

Organizational characteristics drive our selection of the control variables. Firm size and overall sales are included in our model because larger firms should have greater resources, capabilities, and intention to deploy IOS integration with trading partners (Grover and Saeed, 2007).

\section{Control Hypotheses}

We specify the direct effects of exercised power and potential power on IOS integration as control hypotheses for controlling possible spurious effects in the research model. Exercised power and potential power are often suggested as the major forces in facilitating IOS implementation in prior studies (Chan and Chong, 2012; Ke et al., 2009). Hence, their effects on IOS integration are specified as control hypotheses for our research model.

\section{Research Methodology}

\section{Questionnaire Design}

We developed and validated our measures using guidelines in the information systems literature (Straub, 1989). We firstly reviewed prior studies to develop measures that were suitable for the current study, had face validity, and had a minimal overlap between constructs. In order to ensure content validity of the constructs, items were independently evaluated by each of the researchers. The researchers then jointly discussed each construct and its items until they have agreement. After compiling an English-language version of the questionnaire, the survey items were translated into Chinese by a bilingual researcher. The items were verified and refined for translation accuracy by an MIS professor and a PhD candidate. The Chinese version of the draft was then pretested with 4 senior managers (including a CEO and three IS executives) for verifying the face and content validity of the items again, resulting in modification of the wording of some survey items. We operationalized the constructs using multiitem reflective measures with a seven-point Likert scale, ranged from "strongly disagree" to "strongly agree," with its midpoint anchored as "neither agree nor disagree." Table 3 summarizes the operational definitions of the constructs. The survey items are shown in Appendix A.

\begin{tabular}{|l|l|}
\hline \multicolumn{1}{|c|}{ Table 3 - Operational definitions of study constructs } \\
\hline \multicolumn{1}{|c|}{ Constructs } & \multicolumn{1}{c|}{ Operational definition } \\
\hline IOS integration & $\begin{array}{l}\text { The degree of immediately accessing to databases, interconnection of applications, and } \\
\text { data syntactic and semantic integration between a focal firm and its key customer }\end{array}$ \\
\hline Exercised power & $\begin{array}{l}\text { The degree of a focal firm's perception of its key customer exerting influence strategy on } \\
\text { its decision to establish information system integration in support of transactions and } \\
\text { cooperation }\end{array}$ \\
\hline Potential power & $\begin{array}{l}\text { The degree of a focal firm's dependency on its key customer, the proportion of sales and } \\
\text { profits the customer provided, and goal achievement dependent on the customer }\end{array}$ \\
\hline $\begin{array}{l}\text { Competitive } \\
\text { necessity of IOSI }\end{array}$ & $\begin{array}{l}\text { The degree of a focal firm's perception of the necessity of IOS integration for competition } \\
\text { and achievement of goals }\end{array}$ \\
\hline $\begin{array}{l}\text { Interestingness } \\
\text { in IOSI }\end{array}$ & $\begin{array}{l}\text { The degree of which a focal firm is interested in implementing IOS integration due to the } \\
\text { benefits of IOS integration. }\end{array}$ \\
\hline $\begin{array}{l}\text { Firm readiness } \\
\text { for IOSI }\end{array}$ & $\begin{array}{l}\text { The degree of which a focal firm is willing, ready, and doing initial activities to implement } \\
\text { IOS integration. }\end{array}$ \\
\hline
\end{tabular}

The questionnaire was designed to focus on suppliers (focal firms) in channel relationships because suppliers are typically dependent on their key customers for providing the suppliers a large proportion of their sales. Channel relationships could help 
us observe exercised power and potential power, as prior studies did (Hart and Saunders, 1998; Son et al., 2005; Son et al., 2008).

Further, in order to minimize extraneous sources of variance, the respondents were asked to select an important customer who had connected its information systems with the respondent's systems as the base for answering the survey. Any types of systems and any levels of connection are acceptable because, based on innovation diffusion theory (Rogers, 1995), IOS integration is at the stage of assimilation and most trading partners should already adopt IOS to perform at least some simple data exchange (Wu and Chuang, 2010). This method should make the survey more suitable for our research purpose.

\section{Sampling and Data Collection}

A cross-sectional mail survey was administrated for collecting data from selected large and medium-sized manufacturing firms in Taiwan. We selected Top 2000 manufacturing firms from the Year 2012 directory of the Top 5000 Largest Firms in Taiwan, published by China Credit Information Services Ltd. We rule out 29 inadequate firms from our selections, such as government-owned corporation. The final list consisted of 1971 manufacturing firms. We distributed our final version of the survey to the IS executives of these firms. Because the IS function plays a critical role in developing and managing information systems in any firm and its senior managers should also have a good understand of the condition in IOS integration and firm operations with customers, we believe that IS executives should be the most knowledgeable and reliable informants within a company to answer our survey.

After one follow-up mailing, 196 surveys were returned in total with 18 undelivered and invalid ones, yielding a response rate of $10.04 \%$. Of the respondents, 47 came from the firms that had never used information systems to conduct business or transactions with their key customers and therefore were dropped. Due to missing values, the sample size was further reduced to 134 for subsequent analysis. Although the response rate is not high, it is still acceptable to examine our model using partial least squares (PLS) (Hair et al., 2013). According to the recommendation by Hair et al (2013, pp. 21), our sample size can meet the minimum requirement for a statistical power of $80 \%$ when maximum number of arrows pointing at a construct at 3 , significance level at $1 \%$, and minimum $\mathrm{R}^{2}$ above 0.25 . Table 4 exhibits the characteristics of the sample. As the production value of the computer and electronics industries has contributed one-third of Taiwan's GDP and these firms are more advanced in utilizing information and communication technologies, 53 percent of the respondents are from these industries. Automobile, machine, materials, and metals are around 10 percent in the sample.

\section{Table 4 - Profile of the respondents $(\mathrm{N}=134)$}

\begin{tabular}{|c|c|c|c|c|c|}
\hline Industry & No. & $\%$ & Number of employees & No. & $\%$ \\
\hline Automobile & 12 & 9 & $1-250$ & 47 & 35 \\
\hline Chemical & 7 & 5 & $251-500$ & 30 & 22 \\
\hline Computer and electronics & 53 & 40 & $501-1,000$ & 27 & 20 \\
\hline Food & 3 & 2 & $1,001-2,000$ & 12 & 9 \\
\hline Machine and tool & 10 & 7 & $>2,000$ & 18 & 13 \\
\hline Materials & 19 & 14 & & & \\
\cline { 1 - 2 } Metals & 15 & 11 & & &
\end{tabular}


Non-response bias was assessed using the procedure recommended by Armstrong and Overton (1977). Considering the last group of respondents as most likely to be similar to non-respondents, a comparison of the first and last quartile of the respondents provides a test of response bias. No significant differences between the first and last quartile of all respondents were found on our key research variables such as all items IOS integration based on the $t$ test ( $p$ value from 0.289 to 0.904 ). Similar results also appear on other variables such as firm size, the length of association, and frequency of sales $(p=0.181,0.065$, and 0.887 , respectively). Accordingly, nonresponse bias should not be a serious concern in this study.

\section{Data Analysis and Results}

A partial least squares (PLS) structural equation model using SmartPLS Version 3.2.4 was constructed for measurement validation and hypotheses testing. PLS should be appropriate for our study, as it is recommended for smaller sample size, highly complex predictive research models, and non-normal data (Hair et al., 2013). We used SmartPLS to estimate the outer model with a factor weighting scheme and the inner model with a path weighting scheme (Hair et al., 2012; Henseler, 2010). We used non-parametric bootstrapping with 5,000 replications and no sign changes to obtain the estimates (Hair et al., 2013).

\section{Measurement Validation}

We assessed the validity and reliability of the items and constructs according to the guidelines from Hair et al. (2013). The path loadings of all items were significant at $1 \%$ level and the composite reliability (CR) estimates were above 0.9 for all constructs, indicating good internal consistency and the reliability of our scales (Hair et al., 2012). We further assessed the convergent validity using Fornell and Larcker's (1981) average variance extracted (AVE) criterion. All the AVEs exceeded the minimum threshold value of 0.50 (see Table 5) (Fornell and Larcker, 1981; Hair et al., 2012; Henseler et al., 2009). The combined results demonstrated the convergent validity of our constructs. Discriminant validity is established (1) when items load more highly on the construct that they are intended to measure than on other constructs (i.e. loadings should be higher than crossloadings) and (2) when the square root of the average variance extracted (AVE) by each construct is larger than the interconstruct correlations (Chin, 1998; Chin et al., 2003). Without exception, all items loaded more highly on their own construct than on others (see Appendix B). As shown in Table 5, the square root of the AVE for each construct was greater than 0.8 and also greater than the correlations between the construct and other constructs, indicating that all the constructs share more variances with their indicators than with other constructs. Thus, our measures exhibited sufficient discriminant validity.

\section{Table 5 - Inter-construct correlations and reliability measures $(\mathrm{N}=134)$}

\begin{tabular}{|c|c|c|c|c|c|c|c|c|c|c|}
\hline \multirow[b]{2}{*}{ Construct } & \multirow[b]{2}{*}{ Mean } & \multirow[b]{2}{*}{ Std. } & \multirow[b]{2}{*}{ CR. } & \multirow[b]{2}{*}{ AVE } & \multicolumn{6}{|c|}{ Correlations of among constructs } \\
\hline & & & & & 1 & 2 & 3 & 4 & 5 & 6 \\
\hline 1. IOS integration & 3.45 & 1.73 & 0.96 & 0.73 & 0.85 & & & & & \\
\hline 2. Exercised power & 3.75 & 1.86 & 0.96 & 0.89 & 0.65 & 0.94 & & & & \\
\hline 3. Potential power & 4.72 & 1.49 & 0.96 & 0.82 & 0.15 & 0.35 & 0.91 & & & \\
\hline 4. Competitive necessity & 4.80 & 1.51 & 0.97 & 0.92 & 0.62 & 0.55 & 0.27 & 0.96 & & \\
\hline 5. Interestingness in IOS & 4.67 & 1.43 & 0.96 & 0.89 & 0.59 & 0.48 & 0.29 & 0.71 & 0.94 & \\
\hline 6. Firm readiness & 4.25 & 1.49 & 0.95 & 0.87 & 0.62 & 0.53 & 0.31 & 0.68 & 0.75 & 0.93 \\
\hline
\end{tabular}




\section{Safeguards against and Assessment of Common Methods Variance (CMV)}

Common method variance (CMV) is a critical issue in survey research. Thus, we incorporated the measured latent marker variable (MLMV) approach in our survey in order to detect and correct for CMV when using PLS (Chin et al., 2012). This approach requires collecting multiple items that have no nomological relationship with the research items. We followed the guidelines introduced by Chin et al. (2012) and carefully select MLMV indicators. We adopted the items used to measure "trying new features" in Microsoft Office (Sun, 2012) and slightly modified the targeted software to Microsoft Word, which is used more widespread in companies. We then conducted the construct level correction (CLC) approach to partial out the CMV effects at the structural model in our data analysis (Chin et al., 2012). CLC involves creating as many CMV control constructs as there are constructs in research model. Each CMV control uses the same entire set of MLMV items. CMV construct was modeled as impacting each model construct. Consequently, the more accurate estimates of the structural paths can be obtained (Chin et al., 2012).

\section{Results of Hypothesis Testing}

We first assessed multi-collinearity by examining each set of predictor constructs separately for each subpart of the research model (Hair et al., 2013). In our model, all the variance inflation factors (VIF) of endogenous constructs are less than two which is well below the five threshold (Hair et al., 2013), indicating no multi-collinearity problem in our model.

The structural model was assessed to determine the significance of the hypothesized paths and its explanatory power based on the amount of variance accounted for by the endogenous constructs (Chin, 2010). The PLS path coefficients for the research model are shown in Figure 3. The MLMV included in our model are hidden in Figure 3 to simplify the figure. All path coefficients presented are with the CMV effects removed. The full model has a $\mathrm{R}^{2}$ of $55.8 \%$ for IOS integration, indicating that the model explains a substantial amount of variance. $R^{2}$ for firm readiness, competitive necessity, and interestingness of IOS integration are $62.6 \%$, $33.5 \%$, and $53.1 \%$, respectively. $R^{2}$ adjusted values are also shown in Figure 3 . With omission distance equal to 7 , that all the cross-validated redundancy $\mathrm{Q}^{2}$ values of endogenous constructs are larger than zero indicates that the exogenous constructs have predictive relevance for the endogenous constructs under consideration (Chin, 2010). We compare the theoretical model with the saturated model. The results verify that the significant paths in the theoretical model still remain significant in the saturated model.

\section{Testing Direct Effects}

The results from evaluation of the structural model are reported in Figure 3. It can be seen that the path coefficient from exercised power to competitive necessity is significant, supporting $\mathrm{H} 1(\beta=0.553, p<0.01)$. The path coefficient from potential power to the interestingness is significant, supporting $\mathrm{H} 3$ $(\beta=0.127, p<0.1)$. The path coefficient from competitive necessity to interestingness is also significant, supporting $\mathrm{H} 2 \quad(\beta=0.662$, $p<0.01$ ). Likewise, the path coefficient from competitive necessity to firm readiness is significant, supporting $\mathrm{H} 4 \mathrm{a} \quad(\beta=0.299$ $p<0.01)$. The path coefficient from interestingness to firm readiness is also significant, supporting $\mathrm{H} 4 \mathrm{~b} \quad(\beta=0.508$ $p<0.01)$. Finally, we find that the effect of firm readiness on IOS integration is strong with a path coefficient equal to 0.391 $(p<0.01)$, which supports hypothesis H5. All control variables are insignificant. In addition, two control hypotheses are all significant. While exercised power strongly and positively facilitates IOS integration $(\beta=0.472 \quad p<0.01)$, potential power negatively influences IOS integration $(\beta=-$ $0.157 p<0.05)$. Although the path from exercised power to IOS integration is 
significant, we still attempt to examine the

effect of the mediating mechanisms below.

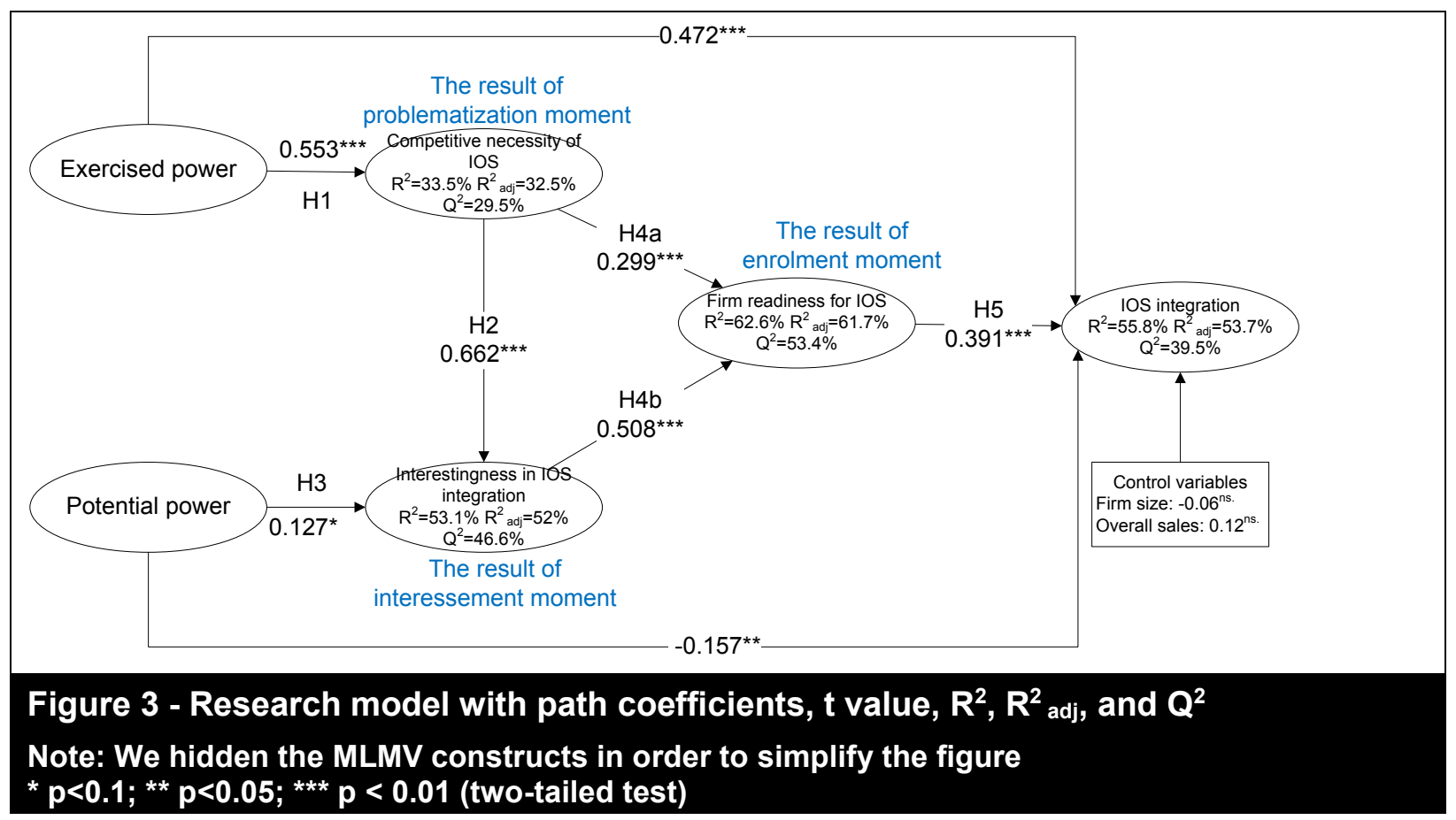

\section{Testing Indirect Effects}

We followed the guidelines suggested by Zhao et al. (2010) for justifying full or partial mediation and conducted the mediation regression method with percentile bootstrap approach for examining the significance of indirect paths (Hayes et al., 2011; Zhao et al., 2010). Such method is more powerful than Sobel test (1982) on Type I error rates (MacKinnon et al., 2002; MacKinnon et al., 2004) because the assumption of a normally distributed sampling distribution for the indirect effect is not easily justified (Hayes et al., 2011; MacKinnon et al., 2004), particularly in small samples (Bollen and Stine, 1990), resulting in higher possibility of bias. We then adopted the simple mediation model (Hayes, 2013; Preacher and Hayes, 2004) and the multiple-step multiple mediator model (Hayes, 2013; Hayes et al., 2011) in order to test the indirect paths with single or multiple mediators in the model. Because these approaches are regression based, we used PLS algorithm to obtain latent variables of the research constructs as inputs (Bradley et al., 2012) for performing the mediation regression method with second-order exact solution and 5,000 resampling on SPSS macros provided by Hayes (2013). Based on these procedures, all indirect paths can be tested reliably and validly.

Table 6 shows the results of the simple mediation models (single mediator). As suggested by Zhao et al. (2010), we first examined the significance of indirect effects. The results indicate that all indirect effects are significant at $p<0.01$ level since zero is excluded in the $99 \%$ confidence interval. We then examined the significance of direct effect from independent variable to dependent variable with the mediator controlled in order to justify full or partial mediation (see column c' in Table 6). Consequently, two of the five mediated paths are full mediation and the rest are partial mediation with all positive indirect effects. 


\begin{tabular}{|c|c|c|c|c|c|c|c|c|c|c|}
\hline Row & Indirect effect & $\begin{array}{c}\text { Graphical } \\
\text { representation }\end{array}$ & c & $\alpha$ & $\beta$ & $c^{\prime}$ & $\alpha \beta$ & $\begin{array}{c}\text { Sobel } \\
\text { z }\end{array}$ & $\begin{array}{c}\text { Bootstrap } \\
95 \% \mathrm{Cl} \\
99 \% \mathrm{Cl}\end{array}$ & Type \\
\hline 1 & $\mathrm{CN} \rightarrow \mathrm{FR} \rightarrow \mathrm{IOSI}$ & $\infty \infty^{x} \rightarrow$ & $\begin{array}{l}0.62 \\
(.00)\end{array}$ & $\begin{array}{l}0.68 \\
(.00)\end{array}$ & $\begin{array}{l}0.37 \\
(.00)\end{array}$ & $\begin{array}{l}0.37 \\
(.00)\end{array}$ & 0.25 & 3.85 & $\begin{array}{l}0.13,0.39 \\
0.08,0.45\end{array}$ & $\begin{array}{c}\text { Partial } \\
\text { mediation }\end{array}$ \\
\hline 2 & $\begin{array}{l}\| \rightarrow F R \rightarrow \\
\text { IOSI }\end{array}$ & $\infty<\rightarrow \infty$ & $\begin{array}{l}0.59 \\
(.00)\end{array}$ & $\begin{array}{l}0.75 \\
(.00)\end{array}$ & $\begin{array}{l}0.40 \\
(.00)\end{array}$ & $\begin{array}{l}0.29 \\
(.00)\end{array}$ & 0.30 & 3.81 & $\begin{array}{l}0.15,0.46 \\
0.09,0.51\end{array}$ & $\begin{array}{c}\text { Partial } \\
\text { mediation }\end{array}$ \\
\hline 3 & $\mathrm{EP} \rightarrow \mathrm{CN} \rightarrow \mathrm{FR}$ & $\rightarrow+\infty$ & $\begin{array}{l}0.53 \\
(.00)\end{array}$ & $\begin{array}{l}0.55 \\
(.00)\end{array}$ & $\begin{array}{l}0.56 \\
(.00)\end{array}$ & $\begin{array}{l}0.23 \\
(.00)\end{array}$ & 0.31 & 5.33 & $\begin{array}{l}0.18,0.44 \\
0.15,0.49\end{array}$ & $\begin{array}{c}\text { Partial } \\
\text { mediation }\end{array}$ \\
\hline 4 & $\mathrm{EP} \rightarrow \mathrm{CN} \rightarrow \|$ & $\rightarrow+\infty$ & $\begin{array}{l}0.48 \\
(.00)\end{array}$ & $\begin{array}{l}0.55 \\
(.00)\end{array}$ & $\begin{array}{l}0.65 \\
(.00)\end{array}$ & $\begin{array}{l}0.12 \\
(.11)\end{array}$ & 0.36 & 5.76 & $\begin{array}{l}0.23,0.50 \\
0.19,0.55\end{array}$ & $\begin{array}{c}\text { Full } \\
\text { mediation }\end{array}$ \\
\hline 5 & $\begin{array}{l}\mathrm{PP} \rightarrow \| I \\
\rightarrow \mathrm{FR}\end{array}$ & $\rightarrow \infty$ & $\begin{array}{l}0.31 \\
(.00)\end{array}$ & $\begin{array}{l}0.29 \\
(.00)\end{array}$ & $\begin{array}{l}0.72 \\
(.00)\end{array}$ & $\begin{array}{l}0.11 \\
(.08)\end{array}$ & 0.21 & 3.31 & $\begin{array}{l}0.06,0.37 \\
0.01,0.40\end{array}$ & $\begin{array}{c}\text { Full } \\
\text { mediation }\end{array}$ \\
\hline \multicolumn{11}{|c|}{$\begin{array}{l}\text { Note: } c=\text { the total effect of independent variable on dependent variable; } \\
\alpha=\text { the effect of independent variable on mediating variable; } \\
\beta=\text { the effect of mediating variable on dependent variable when controlled independent variable; } \\
c^{\prime}=\text { the effect of independent variable on dependent variable when controlled mediating variable } \\
\text { t values shown in parenthesis }\end{array}$} \\
\hline
\end{tabular}

Table 7 summarizes the results of the multiple mediator models. All the multiple mediator paths are significant at $p<0.05$ level. For the first multiple mediator path, it has a significant indirect effect $(\mathrm{M} 1 \& \mathrm{M} 2=$ 0.08 shown in column 'effect'), confirming the effect of exercised power on IOS integration sequentially mediated through competitive necessity and firm readiness. For the second path, it is a higher indirect effect $(M 1 \& M 2=0.18)$ than the other two single-mediator paths $(\mathrm{M} 1=0.13 ; \mathrm{M} 2=$ $0.06)$, confirming the effect of exercised power on firm readiness through competitive necessity and interestingness. For the third path, it is significant and shows the stronger effect $(\mathrm{M} 1 \& \mathrm{M} 2=0.09)$ but insignificant in one of the single-mediator paths $(\mathrm{M} 2=0.04)$, indicating that potential power promotes IOS integration only sequentially through interestingness and firm readiness. We finally examine the longest path from exercised power to IOS integration through competitive necessity, interestingness, and firm readiness (three mediators model) (Hayes, 2013). It is also significant (indirect effect $=0.27$; Bootstrap $95 \% \mathrm{Cl}: 0.16,0.38 ; p<0.05)$. Overall, we conclude that all indirect paths are significant, which corroborates our arguments that exercised and potential power promotes IOS integration through a series of mediating mechanisms.

\section{Discussion}

IOS integration has been proposed as a desirable state in the context of buyersupplier relationships. This study provides new theoretical insights into how exercised and potential power can facilitate IOS integration through a series of mediating mechanisms in a supply chain. Our research model is based on the circuits of power framework and the concepts of OPP and "translation" from ANT to identify the mediators and then develop the hypotheses accordingly. We theorize the mediating effects of competitive necessity, interestingness, and firm readiness between power and IOS integration. Our results suggest that the level of IOS integration tends to be higher when a powerful firm exercises its power to make a dependent firm perceive higher competitive necessity of IOS integration. Without necessarily exercising its power, the powerful firm can still influence the dependent firm to interest 
in integrating IOS between them. These results provide useful guidelines on

implementation of IOS integration.

\begin{tabular}{|c|c|c|c|c|c|c|c|c|c|c|c|}
\hline Row & $\begin{array}{l}\text { Indirect } \\
\text { effect }\end{array}$ & $\begin{array}{c}\text { Graphical } \\
\text { representation }\end{array}$ & $c$ & $\alpha 1$ & $\alpha 2$ & $\alpha 3$ & $\beta 1$ & $\beta 2$ & $c^{\prime}$ & effect & $\begin{array}{c}\text { Bootstrap } \\
95 \% \mathrm{Cl}\end{array}$ \\
\hline 1 & $\begin{array}{l}\mathrm{EP} \rightarrow \mathrm{CN} \\
\rightarrow \mathrm{FR} \rightarrow \mathrm{OOSI}\end{array}$ & $\rightarrow \vec{b}$ & $\begin{array}{l}0.65 \\
(.00)\end{array}$ & $\begin{array}{l}0.55 \\
(.00)\end{array}$ & $\begin{array}{l}0.23 \\
(.00)\end{array}$ & $\begin{array}{l}0.56 \\
(.00)\end{array}$ & $\begin{array}{l}0.24 \\
(.01)\end{array}$ & $\begin{array}{l}0.26 \\
(.00)\end{array}$ & $\begin{array}{l}0.39 \\
(.00)\end{array}$ & $\begin{array}{l}\text { Total: } 0.26 \\
\text { M1: } 0.13 \\
\text { M2: } 0.06 \\
\text { M1\&M2: } 0.08\end{array}$ & $\begin{array}{l}\text { Total: } 0.16,0.39 \\
\text { M1: 0.04, } 0.24 \\
\text { M2: 0.06, } 0.12 \\
\text { M1\&M2: } 0.02,0.16\end{array}$ \\
\hline 2 & $\begin{array}{l}\mathrm{EP} \rightarrow \mathrm{CN} \\
\rightarrow \mathrm{II} \rightarrow \mathrm{FR}\end{array}$ & $\rightarrow 1, \infty$ & $\begin{array}{l}0.53 \\
(.00)\end{array}$ & $\begin{array}{l}0.55 \\
(.00)\end{array}$ & $\begin{array}{l}0.12 \\
(.11)\end{array}$ & $\begin{array}{l}0.65 \\
(.00)\end{array}$ & $\begin{array}{l}0.23 \\
(.01)\end{array}$ & $\begin{array}{l}0.50 \\
(.00)\end{array}$ & $\begin{array}{l}0.17 \\
(.01)\end{array}$ & $\begin{array}{l}\text { Total: } 0.37 \\
\text { M1: } 0.13 \\
\text { M2: } 0.06 \\
\text { M1\&M2: } 0.18\end{array}$ & $\begin{array}{l}\text { Total: } 0.23,0.52 \\
\text { M1: } 0.03,0.25 \\
\text { M2: }-0.02,0.15 \\
\text { M1\&M2: } 0.10,0.28\end{array}$ \\
\hline 3 & $\begin{array}{l}\mathrm{PP} \rightarrow \mathrm{II} \\
\rightarrow \mathrm{FR} \rightarrow \mid \mathrm{OSI}\end{array}$ & $\rightarrow>\rightarrow$ & $\begin{array}{l}0.15 \\
(.09)\end{array}$ & $\begin{array}{l}0.29 \\
(.00)\end{array}$ & $\begin{array}{l}0.11 \\
(.08)\end{array}$ & $\begin{array}{l}0.72 \\
(.00)\end{array}$ & $\begin{array}{l}0.30 \\
(.00)\end{array}$ & $\begin{array}{l}0.42 \\
(.00)\end{array}$ & $\begin{array}{l}-0.07 \\
(.32)\end{array}$ & $\begin{array}{l}\text { Total: } 0.22 \\
\text { M1: } 0.09 \\
\text { M2: } 0.04 \\
\text { M1\&M2: } 0.09 \\
\end{array}$ & $\begin{array}{l}\text { Total: } 0.01,0.35 \\
\text { M1: } 0.01,0.20 \\
\text { M2: }-0.02,0.13 \\
\text { M1\&M2: } 0.02,0.16\end{array}$ \\
\hline \multicolumn{12}{|c|}{$\begin{array}{l}\text { Note: } c=\text { the total effect of independent variable on dependent variable; } \\
\alpha 1=\text { the effect of independent variable on mediating variable } 1 ; \\
\alpha 2=\text { the effect of independent variable on mediating variable } 2 ; \\
\alpha 3=\text { the effect of mediating variable } 1 \text { on mediating variable } 2 ; \\
\beta 1=\text { the effect of mediating variable } 1 \text { on dependent variable when controlled independent variable; } \\
\beta 2=\text { the effect of mediating variable } 2 \text { on dependent variable when controlled independent variable; } \\
c^{\prime}=\text { the effect of independent variable on dependent variable when controlled mediating variable }\end{array}$} \\
\hline
\end{tabular}

\section{Power Effects}

The results indicate that exercised power is useful for the dominant firm to let the dependent firm recognize the competitive necessity of IOS integration $(\mathrm{H} 1)$. Such effect can be realized in two ways. First, the dominant firm can persuade the dependent firm that without an integrated IOS, their business partnership may lose competitiveness. Second, the dominant firm can threaten the dependent firm with the possibility of relationship dissolution. Both ways can bring pressures to the dependent firm.

Our results confirm that potential power of the dominant firm is an effective but, maybe, imperceptible way to translate the dependent firm's identity into IOS integration that can benefit both parties $(\mathrm{H} 3)$. It is reasonable for the dependent firm as implementing IOS integration with the dominant firm is likely to safeguard resources and reduce uncertainty (Casciaro and Piskorski, 2005; Pfeffer and Salancik, 2003), resulting in higher interestingness in IOS integration. Thus, potential power gives the dominant firm the invisible ability to lure the dependent firm to go through interessement.

\section{Mediator Effects and Power}

The association between competitive necessity and interestingness in IOS integration $(\mathrm{H} 2)$ suggests that the dominant firm can raise the dependent firm's interest in IOS integration by arguing the competitiveness of IOS. Our results also show that competitive necessity fully mediates the relationship between exercised power and interestingness. It implies the functional differences of the two types of power in influencing interestingness. While potential power can increase the dependent firm's interestingness (H3), exercised power works through heightened competitive necessity to affect interestingness. Such results imply that 
without arguing convincingly the competitive necessity of IOS integration, the dominant firm's exercised power may lack legitimacy. This can reduce the dependent firm's positive attitudes toward IOS integration, resulting in its interpretation that IOS integration is to serve only the dominant firm's benefits (Hart and Saunders, 1998; Ke et al., 2009; Son et al., 2005; Subramani, 2004). On the other hand, we conducted an additional analysis to examine the relationship between potential power and competitive necessity in order to better understand the functional differences of the two types of power. This additional test shows an insignificant result $(\beta=0.116$, $p>0.1)$. Accordingly, we conclude that the two different types of power have significantly functional differences in generating the mediating mechanisms for IOS integration.

We found that competitive necessity ( $\mathrm{H} 4 \mathrm{a})$ and interestingness $(\mathrm{H} 4 \mathrm{~b})$ are two important drivers for a dependent firm's readiness for IOS integration which, in turn, facilitates IOS integration (H5). Our indirect tests further confirm the mediating role of firm readiness. When we examined the saturated model, the path coefficient from competitive necessity to IOS integration was weak $(\beta=0.172, p<0.1)$ and the path coefficient from interestingness to IOS integration was insignificant $(\beta=0.155, \quad p>0.1)$. Thus, we suggest that reshaping attitudes and values of the dependent firm toward IOS integration, including competitive necessity and interestingness, without necessary initiatives is insufficient to mobilize the dependent firm toward a high level of IOS integration. These results contribute to the literature on IOS that draws on innovation diffusion theory by proposing the parallel effects of external pressures, expected benefits, and firm readiness on IOS (Chwelos et al., 2001; Zhu and Kraemer, 2005; Zhu, Kraemer, Gurbaxani, et al., 2006; Zhu, Kraemer, and Xu, 2006).

In addition, the indirect tests show that exercised power can facilitate firm readiness directly as well as indirectly through competitive necessity, while potential power promotes firm readiness only through interestingness. However, the total effect of exercised power on firm readiness drops significantly when competitive necessity is controlled for (from 0.53 to 0.23 shown in Row 3 of Table 6). Thus, the two types of power have weaker direct effects than competitive necessity and interestingness on firm readiness (shown in Row 3 and Row 5 of Table 6). We conjecture that both powers have effects in reshaping and translating a dependent firm's values and attitudes and thereby inducing it to engage in necessary activities and preparations for IOS integration. These activities may require more involvements that cannot be enforced by mere exercising power, since achieving firm readiness involves a series of internal adjustments during which organizational inertia has to be overcome (Bala and Venkatesh, 2007). Consequently, competitive necessity and interestingness can be the key propositions for dealing with the resistance from organizational inertia.

\section{Overall Indirect Effects of Power}

Overall, our findings suggest that exercising power to suggest the competitive necessity of IOS integration is a useful mechanism for promoting interest in and readiness for the integration, leading to a high level of IOS integration. Potential power, on the other hand, complementarily pushes the "translation." In fact, potential power can go through interestingness and firm readiness to produce an effect on IOS integration. These results confirm the usefulness of the mediating mechanisms for power to promote IOS integration possibly through different paths.

From the theoretical perspective, the results suggest that problematization probably is the most important moment of the "translation" process. When exercised power works well in highlighting the competitive problems during the problematization moment, interessement and enrolment moments can be trigged 
more easily. This can be confirmed by higher path coefficients from competitive necessity to interestingness $(\beta=0.662)$ and to firm readiness $(\beta=0.299)$. Although potential power also can trigger the dependent firm's interestingness $(\beta=0.127)$, the association is much weaker than that between problematization and interestingness $\quad(\beta=0.662)$. Further, enrolment is necessary important for reaching mobilization, confirmed by the path coefficient from firm readiness to IOS integration $(\beta=0.391)$. These findings may suggest that to mobilize to IOS integration through the moments of problematization and enrolment enabled by exercised power is an effective way to promote IOS integration. Although firms can also choose potential power to facilitate IOS integration, such an approach is not so direct and effective and thus may not be producing an unambiguous result. For example, our result shows the direct association between potential power and IOS integration is surprisingly negative $(\beta=-0.157)$.

\section{Implications for Management}

This study provides several key insights that should help managers better understand the effects of exercised and potential power on the implementation of IOS integration.

The first suggestion for managers of the dominant firms is to exercise power appropriately to facilitate IOS integration with the dependent firms. This, however, does not mean that the dominant firms can force the dependent firms to implement IOS integration just coercively, for doing so may incur negative results (Hart and Saunders, 1998). Rather, we suggest that using power to reshape and translate dependent firms' values and attitudes, which leads them to change their extant practices and structures, could be a better approach. As our results, competitive necessity is the base for other moments of translation. Thus, raising competitiveness issues by exercised power can make dependent firms recognize the possible benefits of IOS integration and invest resources in it.
Second, although managers have relatively less control and ability to manipulate potential power due to its nature of ex-ante dependence structure (Casciaro and Piskorski, 2005), potential power is still a useful backing for the managers of dominant firms to lure dependent firms to recognize possible future benefits. With potential power, the managers still can develop some incentive strategies to enable IOS integration even without exercising the power. Potential power can thus motivate the dependent firms to internalize the value of integrating their systems with those of the dominant firms (Ke et al., 2009). Such translation of values and attitudes reduce dependent firms' concerns regarding the intrusive nature of integrated IOS and unbalanced benefit (Subramani, 2004), facilitating the achievement of higher IOS integration at least indirectly.

Third, although our results found that exercised power could promote IOS integration directly, the managers of dominant firms should nevertheless exercise their power more carefully. It is because IOS integration requires a series of changes in values, beliefs, attitudes, rules, practices, and structures of dyadic firms (Grover and Saeed, 2007). Exercised power may compromise dependent firms to implement IOS integration without appropriate "translation" and the necessary changes (Day, 1989). This may put them at potential risks on unilateral conflicted procedures and technologies (Day, 1989). The dependent firms may then establish unnecessary procedures and incur extra costs in order to fulfill the requirements of IOS integration. In this regard, IOS integration may become functional interconnection of dyadic firms' information systems and fail to truly support bilateral governance, which focuses more on joint planning and joint actions (Heide, 1994). Prior studies also show that power fails to facilitate operational and strategic information sharing behaviors even though IOS has been implemented (Madlberger, 2010). Consequently, the benefits of IOS 
integration may still be in favor of dominant firms, which is the main concern of dependent firms. We thus suggest that managers of dominant firms need to keep in mind the risks of exercised power and the maximum benefit of IOS integration must be generated through the co-creation process with dependent firms.

Finally, our results highlight that firm readiness is conducive to IOS integration. To be ready for IOS, firms must achieve a series of initiatives such as compatible interfirm processes and information system configurations (Grover and Saeed, 2007), sufficient financial resources, and top management support (Chwelos et al., 2001). To achieve these, in addition to the direct coercion by exercised power, dominant firms must let dependent firms recognize the competitive necessity and interest in IOS integration. As such, the dependent firms may be more willing to negotiate with the dominant firms and make some concessions on those conflicting issues, thereby achieving greater IOS integration.

\section{Contributions to Research}

This study makes several contributions to the academic literature on IOS. First, although studies on IOS usage are abundant, this area still lacks a comprehensive theory in explaining how power promotes or impedes IOS usage, particularly deeper usage of IOS. Our study draws on the circuits of power framework to elaborate the flows of power and uncover some theoretical blind spots hidden in prior studies. The OPP and "translation" provide the theoretical foundations for us to identify the critical mechanisms that mediate the effects of power on IOS integration. This new perspective may help in developing future research on IOS implementation.

Second, the nature of OPP and "translation" is a process model rather than a variance one, leading to the difficulties of mapping the concepts of a series of events from OPP and translation into the measurable constructs. To tackle these difficulties, we detailed and summarized the concepts of OPP and translation, and mapped them into the mediating constructs of our model. We then measured and confirmed these mediating constructs empirically. We believe our approach complements the process-oriented research that attempts to explain IOS implementation.

Finally, this study extends the existing literature on power and IOS. We believe that our results can deepen our understanding about the mechanisms through which the effects of power can be mediated in IOS development. We also clarify the differences between the two types of power and examine their varying effects on the mediators and then IOS integration. While exercised power is more effective in facilitating some mediators such as competitive necessity, potential power plays a complementary role in motivating the other mediators such as interestingness. Our results may help in resolving the mixed findings of prior studies on the effects of power in facilitating IOS usage.

\section{Limitations and Future Research}

As most empirical studies, our study has several limitations. First, we used perceptual measures, which may not accurately reflect the objective or real relationships among the theoretical constructs we examined. The perceptions of managers largely determine their actions, decisions and outcomes, so such a limitation may not be so serious. Another limitation of this study is the use of a single informant for all measures. Although this technique is common, it creates potential risks of common method variance. We thus adopted the latent marker variable approach to ensuring the absence of common method bias, at least partially. A third limitation is that the cross-sectional nature of the study only provides us with evidence for associations among the constructs. However, the theoretical foundations employed for developing the hypotheses provide justification for the path model presented in this study. Lastly, the 
respondents were asked to select a major customer and it was left to the respondents to decide the customer to select. Assuming that the choice of the relationship will be randomly distributed across the sample, it may have minimal effects on the results.

The following areas need refinement in further research. First, the significances of both direct and indirect paths of exercised power on IOS integration can be considered as complementary mediation suggested by Zhao et al. (2010). Similarly, the significances of negative direct and positive indirect paths of potential power on IOS integration can be considered as competitive mediation (Zhao et al., 2010). Zhao et al. (2010) note that situations may emerge because of the likely omitted mediators in the direct path. Although we have uncovered three mediators with theoretical justification, there may still be omitted mediators to be discovered. More theoretical foundations from different perspectives can be drawn on to uncover them. Second, to strengthen the understanding of the effects of power on IOS development, future research can include more specific variables for measuring different stages of IOS development or diffusion and examine how power affects those stages.

\section{Conclusions}

This study develops an integrative model to elaborate the effects of power on IOS integration based on the concept of translation, which includes the moments of problematization, interessement, enrollment, and finally to mobilization. Accordingly, we identify and demonstrate that competitive necessity, interestingness, and firm readiness are critical in mediating the effects of exercised and potential power on IOS integration. Our results provide four insights to the IOS literature. First, exercised power and potential power have different functional effects on the mediators we identified. While exercised power is able to influence a dependent firm's perceived competitive necessity, potential power can affect its perceived interestingness. Second, exercised power can promote IOS integration through two potential indirect paths: (1) through two mediators competitive necessity and firm readiness; (2) through three mediators - competitive necessity, interestingness, and firm readiness. Third, if a firm is dominant, it can expect its potential power to facilitate IOS integration by making the dependent firm perceive higher interestingness and then lead to greater firm readiness for IOS integration. Fourth, competitive necessity and interestingness are critical in driving firm readiness for IOS integration. These results highlight that the frequently posited contributions of power effects on IOS usage might not be so obvious and direct, and thereby require further investigation.

\section{Acknowledgement}

The financial support provided by MOST of Taiwan under contract no. 100-2410-H-008014 is gratefully acknowledged.

\section{References}

Armstrong, J. S. and Overton, T. S. (1977). "Estimating nonresponse bias in mail surveys," Journal of Marketing Research, 14(3), pp. 396-402.

Bala, H. and Venkatesh, V. (2007). "Assimilation of interorganizational business process standards," Information Systems Research, 18(3), pp. 340-362.

Barua, A., Konana, P., Whinston, A., and Yin, F. (2004). "An empirical investigation of net-enabled business value," MIS Quarterly, 28(4), pp. 585620.

Bollen, K. A. and Stine, R. (1990). "Direct and indirect effects: Classical and bootstrap estimates of variability," Sociological Methodology, 20(1), pp. 115-140. 
Bradley, R. V., Pratt, R. M. E., Byrd, T. A., Outlay, C. N., and Wynn Jr, D. E. (2012). "Enterprise architecture, IT effectiveness and the mediating role of IT alignment in US hospitals," Information Systems Journal, 22(2), pp. 97-127.

Callon, M. (1986). "Some elements of a sociology of translation: domestication of the scallops and the fishermen of St Brieuc Bay," in Law J. (ed.), Power, action and belief: A new sociology of knowledge (Vol. 32, pp. 196-233). London: Routledge.

Callon, M. and Law, J. (1982). "On interests and their transformation: enrolment and counter-enrolment," Social Studies of Science, 12(4), pp. 615-625.

Casciaro, T. and Piskorski, M. J. (2005). "Power imbalance, mutual dependence, and constraint absorption: A closer look at resource dependence theory," Administrative Science Quarterly, 50(2), pp. 167-199.

Chan, F. T. and Chong, A. Y. (2012). "A SEM-neural network approach for understanding determinants of interorganizational system standard adoption and performances," Decision Support Systems, 54(1), pp. 621-630.

Chatfield, A. T. and Yetton, P. (2000). "Strategic payoff from EDI as a function of EDI embeddedness," Journal of Management Information Systems, 16(4), pp. 195-224.

Chin, W. W. (1998). "The partial least squares approach to structural equation modeling," in Marcoulide,s G. A. (Ed.), Modern methods for business research (Vol. 304, pp. 295336). NJ: Lawrence Earlbaum Associates, Hillsdale.

Chin, W. W. (2010). "How to Write Up and Report PLS Analyses," in Vinzi, V. E., Chin, W. W., and Henseler, J. (ed.), Handbook of partial least squares:
Concepts, methods and applications (pp. 655-690). TX: Springer Verlag.

Chin, W. W., Marcolin, B. L., and Newsted, P. R. (2003). "A partial least squares latent variable modeling approach for measuring interaction effects: Results from a Monte Carlo simulation study and an electronic-mail emotion/adoption study," Information Systems Research, 14(2), pp. 189217.

Chin, W. W., Thatcher, J. B., Wright, R. T., and Steel, D. (2012). "Controlling for Common Method Variance in PLS Analysis: The Measured Latent Marker Variable Approach," 7th International Conference on Partial Least Squares and Related Methods, Houston, Texas, USA.

Chwelos, P., Benbasat, I., and Dexter, A. (2001). "Research report: Empirical test of an EDI adoption model," Information Systems Research, 12(3), pp. 304-321.

Clegg, S. (1989). Frameworks of power: Sage Publications Ltd.

Day, J. (1989). "Compromise," Philosophy, 64(250), pp. 471-485.

DiMaggio, P. and Powell, W. (1983). "The iron cage revisited: Institutional isomorphism and collective rationality in organizational fields," American sociological review, 48(2), pp. 147160.

Elbanna, A. R. (2006). "The validity of the improvisation argument in the implementation of rigid technology: the case of ERP systems," Journal of Information Technology, 21(3), pp. 165-175.

Emerson, R. M. (1962). "Powerdependence relations," American Sociological Review, 27(1), pp. 31-41.

Emerson, R. M. (1976). "Social exchange theory," Annual review of sociology, 2, 
pp. 335-362.

Fornell, C. and Larcker, D. F. (1981). "Evaluating structural equation models with unobservable variables and measurement error," Journal of Marketing Research, 18(1), pp. 39-50.

Frazier, G. L., Maltz, E., Antia, K. D., and Rindfleisch, A. (2009). "Distributor sharing of strategic information with suppliers," Journal of Marketing, 73(4), pp. 31-43.

Grover, V. and Saeed, K. A. (2007). "The impact of product, market, and relationship characteristics on interorganizational system integration in manufacturer-supplier dyads," Journal of Management Information Systems, 23(4), pp. 185-216.

Hair, J. F., Hult, G. T. M., Ringle, C., and Sarstedt, M. (2013). A Primer on Partial Least Squares Structural Equation Modeling (PLS-SEM): SAGE Publications, Inc.

Hair, J. F., Sarstedt, M., Ringle, C. M., and Mena, J. A. (2012). "An Assessment of the Use of Partial Least Squares Structural Equation Modeling in Marketing Research," Journal of the Academy of Marketing Science, 40(3), pp. 414-433.

Hart, P. and Saunders, C. (1997). "Power and trust: Critical factors in the adoption and use of electronic data interchange," Organization science, 8(1), pp. 23-42.

Hart, P. and Saunders, C. (1998). "Emerging electronic partnerships: Antecedents and dimensions of EDI use from the supplier's perspective," Journal of Management Information Systems, 14(4), pp. 87-111.

Hayes, A. F. (2013). Introduction to mediation, moderation, and conditional process analysis: $A$ regression-based approach: Guilford Press.
Hayes, A. F., Preacher, K. J., and Myers, T. A. (2011). "Mediation and the estimation of indirect effects in political communication research," in Bucy, E. P. and Holbert, R. L. (ed.), Sourcebook for political communication research: Methods, measures, and analytical techniques (pp. 434-465). New York: Routledge.

Heide, J. B. (1994). "Interorganizational governance in marketing channels," Journal of Marketing, 58(1), pp. 71-85.

Henseler, J. (2010). "On the Convergence of the Partial Least Squares Path Modeling Algorithm," Computational Statistics, 25(1), pp. 107-120. doi:10.1007/s00180-009-0164-x

Henseler, J., Ringle, C. M., and Sinkovics, R. R. (2009). "The Use of Partial Least Squares Path Modeling in International Marketing," in Sinkovics, R. R. and Ghauri, P. N. (ed.), Advances in International Marketing (Vol. 20, pp. 277-320). Bingley: Emerald

Huang, Z., Janz, B. D., and Frolick, M. N. (2008). "A comprehensive examination of Internet-EDI adoption," Information Systems Management, 25(3), pp. 273-286.

lacovou, C. L., Benbasat, I., and Dexter, A. S. (1995). "Electronic data interchange and small organizations: Adoption and impact of technology," MIS Quarterly, 19(4), pp. 465-485.

Iskandar, B. Y., Kurokawa, S., and LeBlanc, L. J. (2001). "Adoption of electronic data interchange: the role of buyersupplier relationships," IEEE Transactions on Engineering Management, 48(4), pp. 505-517.

Kambil, A. and Short, J. (1994). "Electronic integration and business network redesign: A roles-linkage perspective," Journal of Management Information Systems, 10(4), pp. 59-83. 
Katz, M. L. and Shapiro, C. (1985). "Network externalities, competition, and compatibility," The American economic review, 75(3), pp. 424-440.

Kauremaa, J., Nurmilaakso, J. M., and Tanskanen, K. (2010). "E-business enabled operational linkages: The role of RosettaNet in integrating the telecommunications supply chain," International Journal of Production Economics, 127(2), pp. 343-357.

Ke, W., Liu, H., Wei, K., Gu, J., and Chen, H. (2009). "How do mediated and nonmediated power affect electronic supply chain management system adoption? The mediating effects of trust and institutional pressures," Decision Support Systems, 46(4), pp. 839-851.

Kim, K., Umanath, N., and Kim, B. (2005-6). "An assessment of electronic information transfer in B2B supplychannel relationships," Journal of Management Information Systems, 22(3), pp. 294-320.

Kumar, K. and van Dissel, H. G. (1996). "Sustainable collaboration: Managing conflict and cooperation in interorganizational systems," MIS Quarterly, 20(3), pp. 279-300.

Kumar, N., Scheer, L. K., and Steenkamp, J. B. E. M. (1995). "The effects of perceived interdependence on dealer attitudes," Journal of Marketing Research, 32(3), pp. 348-356.

Latour, B. (1987). Science in action: How to follow scientists and engineers through society: Harvard Univ Pr.

Law, J. (1986). "On the methods of longdistance control: vessels, navigation and the Portuguese route to India," in Law, J. (ed.), Power, action and belief: A new sociology of knowledge (Vol. 32, pp. 234-263). London: Routledge.

Lee, S. and Lim, G. (2005). "The impact of partnership attributes on EDI implementation success," Information \& Management, 42(4), pp. 503-516.

Lu, X., Huang, L., and Heng, M. (2006). "Critical success factors of interorganizational information systems-A case study of Cisco and Xiao Tong in China," Information \& Management, 43(3), pp. 395-408.

Lukes, S. (1974). Power: A radical view, Palgrave Macmillan.

Lusch, R. F. and Brown, J. R. (1996). "Interdependency, contracting, and relational behavior in marketing channels," Journal of Marketing, 60(4), pp. 19-38.

MacKinnon, D. P., Lockwood, C. M., Hoffman, J. M., West, S. G., and Sheets, V. (2002). "A comparison of methods to test mediation and other intervening variable effects," Psychological Methods, 7(1), pp. 83118.

MacKinnon, D. P., Lockwood, C. M., and Williams, J. (2004). "Confidence limits for the indirect effect: Distribution of the product and resampling methods," Multivariate Behavioral Research, 39(1), pp. 99-128.

Madlberger, M. (2010). "What drives firms to engage in interorganizational information sharing in supply chain management?" in Kock, N. (ed.), ECollaboration Technologies and Organizational Performance: Current and Future Trends: Current and Future Trends (pp. 101-123). USA: Texas A\&M International University.

Mohr, J. and Spekman, R. (1994). "Characteristics of partnership success: Partnership attributes, communication behavior, and conflict resolution techniques," Strategic management journal, 15(2), pp. 135152.

Mohr, L. (1982). Explaining organizational behavior (Vol. 1): Jossey-Bass San Francisco. 
Narayanan, S., Marucheck, A., and Handfield, R. (2009). "Electronic Data Interchange: Research Review and Future Directions," Decision Sciences, 40(1), pp. 121-163.

Newman, M. and Robey, D. (1992). "A social process model of user-analyst relationships," MIS Quarterly, 16(2), pp. 249-266.

Pfeffer, J. and Salancik, G. (2003). The external control of organizations: $A$ resource dependence perspective: Stanford Business Books.

Preacher, K. J. and Hayes, A. F. (2004). "SPSS and SAS procedures for estimating indirect effects in simple mediation models," Behavior Research Methods, 36(4), pp. 717731.

Premkumar, G. and Ramamurthy, K. (1995). "The Role of Interorganizational and Organizational Factors on the Decision Mode for Adoption of Interorganizational Systems," Decision Sciences, 26(3), pp. 303-336.

Provan, K., Beyer, J., and Kruytbosch, C. (1980). "Environmental linkages and power in resource-dependence relations between organizations," Administrative Science Quarterly, 25(2), pp. 200-225.

Rai, A., Patnayakuni, R., and Patnayakuni, N. (2006). "Firm performance impacts of digitally enabled supply chain integration capabilities," MIS Quarterly, $30(2)$, pp. 225-246.

Rai, A. and Tang, X. L. (2010). "Leveraging IT Capabilities and Competitive Process Capabilities for the Management of Interorganizational Relationship Portfolios," Information Systems Research, 21(3), pp. 516542.

Ramamurthy, K., Premkumar, G., and Crum, M. (1999). "Organizational and interorganizational determinants of EDI diffusion and organizational performance: A causal model," Journal of Organizational Computing and Electronic Commerce, 9(4), pp. 253-285.

Ranganathan, C., Dhaliwal, J. S., and Teo, T. S. H. (2004). "Assimilation and diffusion of web technologies in supply-chain management: an examination of key drivers and performance impacts," International Journal of Electronic Commerce, 9(1), pp. 127-161.

Redondo, E., Daniel, E., and Ward, J. (2009). "Combining the rational and relational perspectives of electronic trading," European Journal of Information Systems, 18(1), pp. 79-97.

Riggins, F., and Mukhopadhyay, T. (1994). "Interdependent benefits from interorganizational systems: opportunities for business partner reengineering," Journal of Management Information Systems, 11(2), pp. 37-57.

Robey, D., Im, G., and Wareham, J. (2008). "Theoretical foundations of empirical research on interorganizational systems: assessing past contributions and guiding future directions," Journal of the Association for Information Systems, 9(9), pp. 497-518.

Rodon, J., Pastor, J. A., Sesé, F., and Christiaanse, E. (2008). "Unravelling the dynamics of IOIS implementation: an actor-network study of an IOIS in the seaport of Barcelona," Journal of Information Technology, 23(2), pp. 97108.

Rodon, J. and Sese, F. (2010). "Analysing IOIS adoption through structural contradictions," European Journal of Information Systems, 19(6), pp. 637648.

Rogers, E. M. (1995). Diffusion of innovation (Vol. 4): New York: Free Press. 
Saeed, K. A., Malhotra, M. K., and Grover, V. (2011). "Interorganizational system characteristics and supply chain integration: An empirical assessment," Decision Sciences, 42(1), pp. 7-42.

Saraf, N., Langdon, C. S., and Gosain, S. (2007). "IS application capabilities and relational value in interfirm partnerships," Information Systems Research, 18(3), pp. 320-339.

Sarker, S. and Sidorova, A. (2006). "Understanding business process change failure: An actor-network perspective," Journal of Management Information Systems, 23(1), pp. 51-86.

Silva, L. (2007). "Epistemological and theoretical challenges for studying power and politics in information systems," Information Systems Journal, 17(2), pp. 165-183.

Sobel, M. E. (1982). "Asymptotic confidence intervals for indirect effects in structural equation models," Sociological Methodology, 13(1982), pp. 290-312.

Son, J. Y., and Benbasat, I. (2007). "Organizational buyers' adoption and use of B2B electronic marketplaces: efficiency-and legitimacy-oriented perspectives," Journal of Management Information Systems, 24(1), pp. 55-99.

Son, J. Y., Narasimhan, S., and Riggins, F. (2005). "Effects of relational factors and channel climate on EDI usage in the customer-supplier relationship," Journal of Management Information Systems, 22(1), pp. 321-353.

Son, J. Y., Narasimhan, S., Riggins, F. J., and Kim, N. (2008). "Understanding the development of IOS-based trading partner relationships: A structural model with empirical validation," Journal of Organizational Computing and Electronic Commerce, 18(1), pp. 34-60.
Straub, D. W. (1989). "Validating instruments in MIS research," MIS Quarterly, 13(2), pp. 147-169.

Subramani, M. (2004). "How do suppliers benefit from information technology use in supply chain relationships?," MIS Quarterly, 28(1), pp. 45-73.

Sun, H. (2012). "Understanding user revisions when using information system features: Adaptive system use and triggers," MIS Quarterly, 36(2), pp. 453-478.

Teo, H., Wei, K. and Benbasat, I. (2003). "Predicting intention to adopt interorganizational linkages: An institutional perspective," MIS Quarterly, 27(1), pp. 19-49.

Van de Ven, A. H. (2007). Engaged scholarship: A guide for organizational and social research: Oxford University Press, USA.

Wu, I. L. and Chuang, C. H. (2010). "Examining the diffusion of electronic supply chain management with external antecedents and firm performance: A multi-stage analysis," Decision Support Systems, 50(1), pp. 103-115.

Yao, Y., Palmer, J., and Dresner, M. (2007). "An interorganizational perspective on the use of electronically-enabled supply chains," Decision Support Systems, 43(3), pp. 884-896.

Zhang, C. and Dhaliwal, J. (2009). "An investigation of resource-based and institutional theoretic factors in technology adoption for operations and supply chain management," International Journal of Production Economics, 120(1), pp. 252-269.

Zhao, X., Lynch, J. G., and Chen, Q. (2010). "Reconsidering Baron and Kenny: Myths and truths about mediation analysis," Journal of Consumer Research, 37(2), pp. 197-206. 
Zhu, K. and Kraemer, K. L. (2005). "Postadoption variations in usage and value of e-business by organizations: crosscountry evidence from the retail industry," Information Systems Research, 16(1), pp. 61-84.

Zhu, K., Kraemer, K. L., Gurbaxani, V., and Xu, S. X. (2006). "Migration to openstandard interorganizational systems: Network effects, switching costs, and path dependency," MIS Quarterly, 30(Special issue), pp. 515-539.

Zhu, K., Kraemer, K. L., and Xu, S. (2006). "The process of innovation assimilation by firms in different countries: a technology diffusion perspective on e-business," Management science, 52(10), pp. 1557-1576. 


\section{Appendix A: Scale indicators and literature sources}

\begin{tabular}{|c|c|}
\hline Scale indicators & References \\
\hline $\begin{array}{l}\text { IOS integration (IOSI) } \\
\text { Data are entered only once to be retrieved by this customer's system (e.g., production, } \\
\text { shipment, inventory, order status, etc.). } \\
\text { We can easily share our data with this customer (e.g., production, shipment, inventory, } \\
\text { etc.). } \\
\text { We have successfully integrated relevant applications of our system with this customer's } \\
\text { applications (e.g., manufacturing, planning, order management, inventory } \\
\text { management, sales, etc.). } \\
\text { Our applications work seamlessly with this customer's applications (e.g., manufacturing, } \\
\text { planning, order management, inventory management, etc.). } \\
\text { Our applications can share real-time information with this customer's applications (e.g., } \\
\text { order changes, manufacturing progress, manufacturing schedule, inventory } \\
\text { information, etc.). } \\
\text { Our applications relevant to customer (such as order management, shipment } \\
\text { management, etc.) and our internal applications (such as ERP) are integrated. } \\
\text { We have synchronized data formats and standards with this customer. } \\
\text { The data formats and standards used in the systems of our firm and this customer are } \\
\text { based on a common standard. } \\
\text { Dropped item: Our system can access the data from this customer's system (e.g., order, } \\
\text { sales, inventory, etc.). } \\
\text { Dropped item: Our system can aggregate relevant information from this customer's } \\
\text { databases (e.g., order, sales, inventory, etc.). } \\
\text { Dropped item: Definitions of key data elements (such as order and part numbers) are } \\
\text { common between ours and this customer's system. }\end{array}$ & $\begin{array}{l}\text { Saraf et al. (2007) } \\
\text { Rai and Tang (2010) } \\
\text { Grover and Saeed } \\
(2007) \\
\text { Saeed et al. (2011) } \\
\text { Rai et al. (2006) }\end{array}$ \\
\hline $\begin{array}{l}\text { Exercised power (EP) } \\
\text { This customer has influenced our decision to establish information system integration with } \\
\text { them for business transactions. } \\
\text { This customer has influenced our decision to establish information system integration with } \\
\text { them in support of interfirm operation activities. } \\
\text { This customer was the main force behind our firm establishing integration between our } \\
\text { systems and theirs. }\end{array}$ & $\begin{array}{l}\text { Son et al. (2005) } \\
\text { Hart and Saunders } \\
(1998)\end{array}$ \\
\hline $\begin{array}{l}\text { Potential power (PP) } \\
\text { We are dependent on this customer. } \\
\text { This customer is very important to the achievement of our organizational goals. } \\
\text { This customer would be difficult to replace. } \\
\text { This customer would be costly to lose } \\
\text { The proportion of total sales that relate to sales with this customer is very high. } \\
\text { The proportion of total profits that relate to profits from sale to this customer is very high. }\end{array}$ & $\begin{array}{l}\text { Grover and Saeed } \\
(2007) \\
\text { Lusch and Brown } \\
\text { (1996) } \\
\text { Premkumar and } \\
\text { Ramamurthy (1995) }\end{array}$ \\
\hline $\begin{array}{l}\text { Competitive necessity of IOS integration (CN) } \\
\text { Our firm recognizes that establishing IOS integration with this customer is competitive } \\
\text { necessity. } \\
\text { Our firm recognizes that establishing IOS integration with this customer can enhance our } \\
\text { competitive advantages. } \\
\text { Our firm recognizes that establishing IOS integration with this customer is the } \\
\text { indispensability of solution to the achievement of our organizational goals. }\end{array}$ & $\begin{array}{l}\text { Callon and Law } \\
(1982) \\
\text { Callon (1986) }\end{array}$ \\
\hline $\begin{array}{l}\text { Interestingness in IOS integration (II) } \\
\text { Our firm is interested in establishing IOS integration with this customer. } \\
\text { Our firm identifies that establishing IOS integration with this customer can benefit us. } \\
\text { Our firm's identity toward establishing IOS integration with this customer is positive. }\end{array}$ & $\begin{array}{l}\text { Callon and Law } \\
(1982) \\
\text { Callon (1986) }\end{array}$ \\
\hline $\begin{array}{l}\text { Firm readiness for IOS integration (FR) } \\
\text { Before establishing IOS integration with this customer, our firm is ready for doing it. } \\
\text { Before establishing IOS integration with this customer, our firm is willing to invest } \\
\text { necessary resources in doing it. } \\
\text { Before establishing IOS integration with this customer, our firm is doing initial activities for } \\
\text { doing it. }\end{array}$ & $\begin{array}{l}\text { Callon and Law } \\
(1982) \\
\text { Callon (1986) }\end{array}$ \\
\hline $\begin{array}{l}\text { Measured latent marker variable (MLMV) } \\
\text { I played around with features in Microsoft Word. } \\
\text { I used some Microsoft Word features by trial and error. } \\
\text { I tried new features in Microsoft Word. } \\
\text { I figured out how to use certain Microsoft Word features. }\end{array}$ & Sun (2012) \\
\hline
\end{tabular}




\section{Appendix B: Outer model loadings and cross loadings}

\begin{tabular}{|l|l|l|l|l|l|l|}
\hline Constructs & 1 & 2 & 3 & 4 & 5 & 6 \\
\hline 1. IOS integration & & & & & & \\
\hline IOSI1 & $\mathbf{0 . 8 0}$ & 0.47 & 0.00 & 0.48 & 0.42 & 0.46 \\
\hline IOSI2 & $\mathbf{0 . 8 3}$ & 0.62 & 0.18 & 0.58 & 0.51 & 0.50 \\
\hline IOSI3 & $\mathbf{0 . 8 4}$ & 0.57 & 0.12 & 0.54 & 0.45 & 0.50 \\
\hline IOSI4 & $\mathbf{0 . 8 8}$ & 0.56 & 0.13 & 0.56 & 0.46 & 0.49 \\
\hline IOSI5 & $\mathbf{0 . 9 1}$ & 0.52 & 0.16 & 0.53 & 0.54 & 0.56 \\
\hline IOSI6 & $\mathbf{0 . 8 4}$ & 0.51 & 0.11 & 0.51 & 0.54 & 0.58 \\
\hline IOSI7 & $\mathbf{0 . 8 6}$ & 0.60 & 0.17 & 0.52 & 0.56 & 0.57 \\
\hline IOSI8 & $\mathbf{0 . 8 7}$ & 0.58 & 0.13 & 0.52 & 0.54 & 0.55 \\
\hline 2. Exercised power & & & & & & \\
\hline EP1 & 0.63 & $\mathbf{0 . 9 6}$ & 0.35 & 0.53 & 0.46 & 0.53 \\
\hline EP2 & 0.61 & $\mathbf{0 . 9 5}$ & 0.30 & 0.51 & 0.42 & 0.49 \\
\hline EP3 & 0.61 & $\mathbf{0 . 9 2}$ & 0.34 & 0.52 & 0.46 & 0.49 \\
\hline 3. Potential power & & & & & & \\
\hline PP1 & 0.15 & 0.34 & $\mathbf{0 . 8 6}$ & 0.29 & 0.27 & 0.31 \\
\hline PP2 & 0.18 & 0.37 & $\mathbf{0 . 9 3}$ & 0.31 & 0.33 & 0.33 \\
\hline PP3 & 0.13 & 0.33 & $\mathbf{0 . 9 3}$ & 0.24 & 0.29 & 0.31 \\
\hline PP4 & 0.10 & 0.28 & $\mathbf{0 . 9 1}$ & 0.21 & 0.22 & 0.25 \\
\hline PP5 & 0.07 & 0.25 & $\mathbf{0 . 9 1}$ & 0.17 & 0.20 & 0.22 \\
\hline PP6 & 0.12 & 0.28 & $\mathbf{0 . 8 8}$ & 0.17 & 0.20 & 0.23 \\
\hline 4. Competitive necessity & & & & & & \\
\hline CN1 & 0.59 & 0.52 & 0.17 & $\mathbf{0 . 9 6}$ & 0.67 & 0.62 \\
\hline CN2 & 0.59 & 0.52 & 0.32 & $\mathbf{0 . 9 6}$ & 0.71 & 0.66 \\
\hline CN3 & 0.60 & 0.54 & 0.27 & $\mathbf{0 . 9 5}$ & 0.67 & 0.68 \\
\hline 5. Interestingness in IOS integration & & & & & & \\
\hline II1 & 0.57 & 0.45 & 0.25 & 0.65 & $\mathbf{0 . 9 2}$ & 0.70 \\
\hline II2 & 0.55 & 0.47 & 0.30 & 0.71 & $\mathbf{0 . 9 6}$ & 0.73 \\
\hline II3 & 0.56 & 0.42 & 0.27 & 0.66 & $\mathbf{0 . 9 5}$ & 0.69 \\
\hline 6. Firm readiness for IOS integration & & & & & & \\
\hline FR1 & 0.56 & 0.49 & 0.33 & 0.58 & 0.64 & $\mathbf{0}$ \\
\hline FR2 & 0.54 & 0.44 & 0.30 & 0.69 & 0.76 & $\mathbf{0 . 9 4}$ \\
\hline FR3 & 0.63 & 0.56 & 0.25 & 0.64 & 0.70 & $\mathbf{0 . 9 5}$ \\
\hline
\end{tabular}

\section{About the Authors}

Neil Chueh-An Lee is an assistant professor in the Department of Business Administration at Ming Chuan University, Taiwan (R.O.C.). He received his Ph.D. in Information Management from National Central University, Taiwan. This research interests include supply chain management, enterprise systems, and inter-firm relationship and collaboration. His research has appeared in Information \& Management and leading international conferences proceedings.

Eric T. G. Wang is Chaired Professor in the Department of Information Management at National Central University, Taiwan (R.O.C.). $\mathrm{He}$ received his Ph.D. degree in Business
Administration, with a specialization in in computer and information systems, from the William E. Simon Graduate School of Business Administration, University of Rochester. His research interests include electronic commerce, supply chain management, outsourcing, organizational economics, and organizational impact of information technology. His research has appeared in MIS Quarterly, Information Systems Research, Management Science, Journal of Management Information Management, Decision Sciences, European Journal of Information Systems, Information Systems Journal, Decision Support Systems, Information \& Management, Omega, European Journal of Operational Research, and others. 